\title{
Globally Significant Plants in Southeastern Big Horn and Southwestern Rosebud Counties, Montana
}

Prepared for:

The Bureau of Land Management

\begin{abstract}
By:
Drake Barton and Sue Crispin

Montana Natural Heritage Program

Natural Resource Information System

Montana State Library
\end{abstract}

February 2003

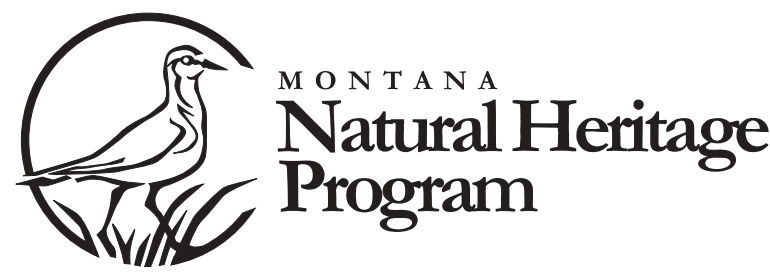




\title{
Globally Significant Plants in Southeastern Big Horn and Southwestern Rosebud Counties, Montana
}

\author{
Prepared for: \\ Bureau of Land Management \\ Miles City Field Office \\ 111 Garryowen Rd. Miles City, MT 59301 \\ Agreement \# ESA010009 Task \# 5 \\ By: \\ Drake Barton and Sue Crispin \\ Montana Natural Heritage Program

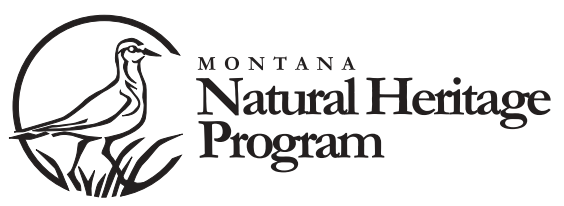

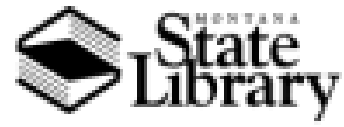

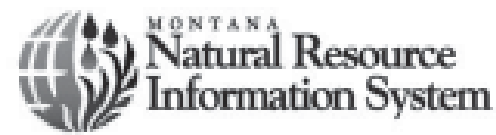

(C) 2003 Montana Natural Heritage Program

P.O. Box 2018001515 East Sixth Ave Helena, MT 59620-1800 406-444-3009

This document should be cited as follows:

Barton, D. and S. Crispin. 2003. Globally Significant Plants in Southeastern Big Horn and Southwestern Rosebud Counties, Montana. Montana Natural Heritage Program, Helena. 27 pp. plus appendices. 


\section{Acknowledgements}

Many thanks to all the individuals who contributed to this project. A special thanks to Louise de Montigny, Bureau of Land Management, Miles City Field Office, for providing logistical support, and to Kent Undlin, Dawn Doran and Jeff Gustad from the Field Office for their accompaniment in the field. Thanks to Amy Taylor who conducted fieldwork in 2001. Thanks to Ron Hartman for use of the Rocky Mountain Herbarium in Laramie,
Wyoming, and Dave Dyer for access to the University of Montana Herbarium in Missoula, Montana for specimen identification. Thanks also to Spring Creek Coal for access to known locations of Sensitive plants. Another special thanks to all the landowners who provided access to conduct surveys, much needed directions and ice tea after a hot field day. 


\section{Executive Summary}

In 2001 and 2002, botanists for the Montana Natural Heritage Program (MTNHP) conducted field surveys to locate Astragalus barrii (Barr's milkvetch) and Physaria didymocarpa var. lanata (woolly twinpod) in southeastern Big Horn County and southwestern Rosebud County. Both of these species are regional endemics, their overall range being restricted to portions of adjacent Montana, Wyoming and South Dakota. A. barrii is ranked G3 S2S3 (vulnerable at both global and state levels) by the Natural Heritage Network (Heidel 2001) and is recognized as a Watch Species by the BLM Montana Office. $P$. didymocarpa var. lanata is ranked G5T2 $\mathrm{S} 1$ (indicating the variety is vulnerable at both global and state levels) by the Natural Heritage Network and has not yet been designated as a Sensitive or Watch Species by the BLM Montana Office.

Previous to this study, both $A$. barrii and $P$. didymocarpa var. lanata were known to occur within the area but had not been systematically inventoried. $P$. didymocarpa var. lanata was known in Montana from only one location in Big Horn County and had been documented from 14 occurrences in north-central Wyoming. A. barrii had previously been documented from 33 locations in southeastern Montana, only two of those in southeastern Big Horn and southwestern Rosebud counties.

We identified potential habitat for Astragalus barrii and Physaria didymocarpa var. lanata prior to beginning fieldwork, using USGS topo- graphic maps, soil data (Soil Survey 1996) and information in the MTNHP databases. Surveys were conducted mainly on larger blocks of public land where appropriate habitat was identified, and included a total of 25 survey routes.

These surveys resulted in discovery of four new occurrences of $P$. didymocarpa var. lanata and three new occurrences of $A$. barrii. In addition, two new locations were found for another globally significant Species of Concern, Lomatium nuttallii (Nuttall's desert-parsley). This species is a regional endemic, presently ranked G3 S1, and was previously known in Montana from one 1980 collection in Big Horn County. This species is designated as a Watch Species by the BLM in Montana (BLM 1996).

These surveys generated significant new information on the distribution and habitat of globally significant plant species in this area, particularly for $P$. didymocarpa var. lanata and $L$. nuttallii, both of which had only one known occurrence in Montana prior to 2001. The fact that our surveys were often unsuccessful in areas of apparently suitable habitat reinforces that these species are uncommon to rare, and do not occur predictably and regularly in apparently suitable habitat. However, given the relatively small proportion of potential habitat that we surveyed, additional populations likely exist for all three species in unsurveyed areas of suitable habitat scattered throughout the region. 


\section{Table of Contents}

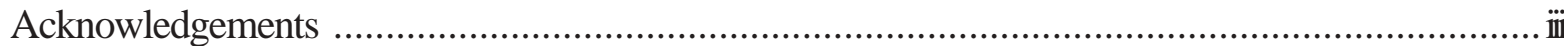

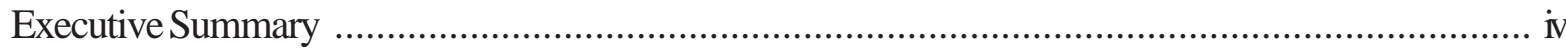

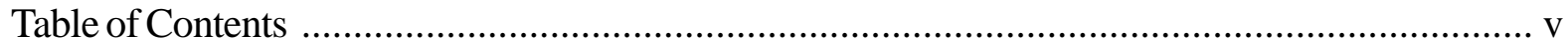

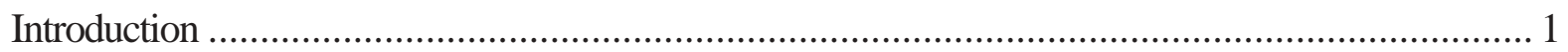

Study Area

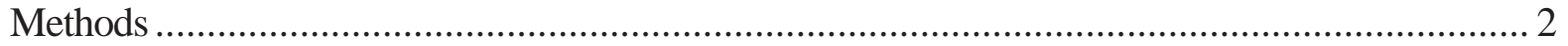

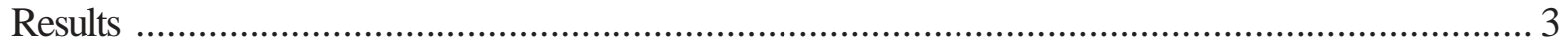

Astragalus barrii (Barr's milkvetch) .............................................................................. 4

Physaria didymocarpa var. lanata (woolly twinpod) ……................................................ 10

Lomatium nuttallii (Nuttall's desert-parsley) ............................................................... 17

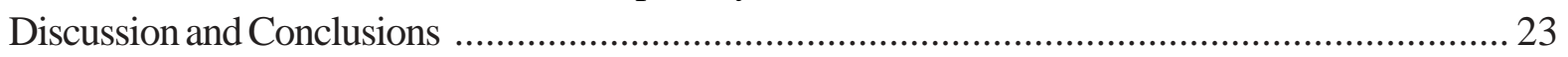

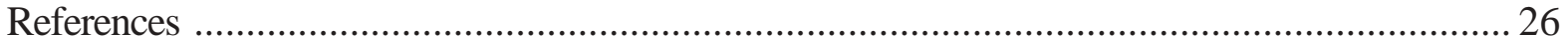

\section{Appendices}

Appendix 1. Global / State Rank Definitions

Appendix 2. Maps of the Search Routes

\section{List of Figures}

Figure 1. The five occurrence records for A. barrii in the study area. ......................................... 6

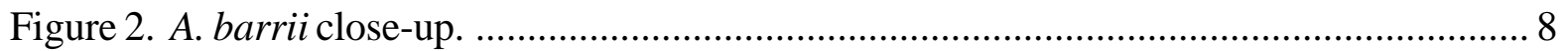

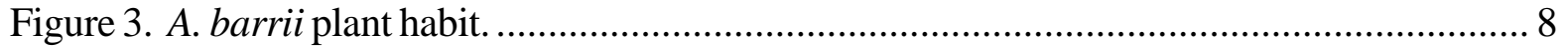

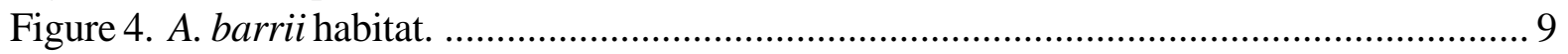

Figure 5. A. barrii habitat. ........................................................................................... 9

Figure 6. The five occurrence records for P. didymocarpa var. lanata in the study area............ 12

Figure 7. P. didymocarpa var. lanata Fruiting plant habitat. ................................................. 15

Figure 8. P. didymocarpa var. lanata plant habitat............................................................. 15

Figure 9. P. didymocarpa var. lanata plant with fruits. ........................................................... 16

Figure 10. P. didymocarpa var. didymocarpa plant in flower. ................................................ 16

Figure 11. The three occurrence records for L. nuttallii in the study area................................. 19

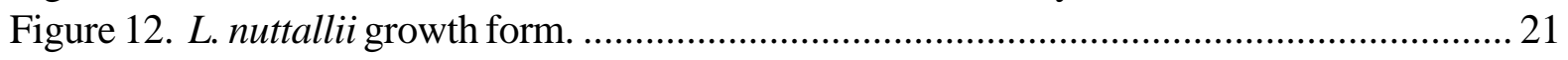

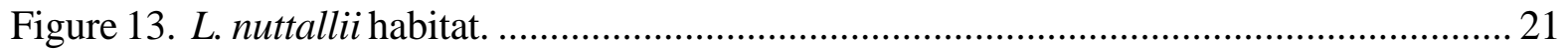

Figure 14. L. nuttallii close-up showing leaf characteristics. ................................................... 22

Figure 15. L. nuttallii close-up showing fruit characteristics.................................................. 22

\section{List of Tables}

Table 1. Element Occurrence records for A. barrii in the project study area................................ 7

Table 2. Element Occurrence records for $P$. didymocarpa var. lanata in the study area. ........... 13

Table 3. Element Occurrence records for $L$. nuttallii in the project study area. ......................... 20 


\section{Introduction}

In 2001 and 2002, botanists from the Montana Natural Heritage Program (MTNHP) conducted field surveys for the Bureau of Land Management (BLM), Miles City Field Office to locate and collect additional data on globally significant plant species in southeastern Big Horn County and southwestern Rosebud County. The purpose of this study was to identify additional populations or potential habitat, and in the process develop a better understanding of the habitat characteristics of these species. The information gathered would also be helpful in identifying factors that could affect the long-term viability of these taxa in the area and inform effective management. The survey focused on lands administered by the Bureau of Land Management, but also included state land and occasionally private land when the landowner granted permission.

The primary survey targets were Astragalus barrii (Barr's milkvetch) and Physaria didymocarpa var. lanata (woolly twinpod), both Montana Species of Concern and regional endemics, their overall range being restricted primarily to adjacent Montana, Wyoming and South Dakota. Barr's milkvetch is ranked G3 S2S3 (vulnerable at both global and state levels) by the Natural Heritage Network (Heidel 2001) and is recognized as a Watch Species by the BLM Montana Office (BLM 1996). Woolly twinpod is ranked G5T2 S1, indicating that while the species is globally common, this variety is globally rare/ restricted and is extremely rare in Montana (Heidel 2001). Woolly twinpod has not yet been designated as a Sensitive or Watch Species by the BLM Montana Office.

Both Barr's milkvetch and woolly twinpod were previously documented within the study area, but had not been systematically inventoried. Prior to this survey, woolly twinpod was known in Montana from only one location in Big Horn County. Outside of Montana the Wyoming Natural Diversity Database has documented an additional 14 occurrences in northcentral Wyoming. Barr's milkvetch occurs in South Dakota and Wyoming, and had previously been documented from 33 locations in southeastern Montana, two of which were located within the study area.

Other Species of Concern documented from this area were also sought, though not as vigorously in the course of our surveys. Among them was Lomatium nuttallii (Nuttall's desert-parsley), ranked G3 S1 and previously known in Montana from one 1980 collection in Big Horn County. Nuttall's desert-parsley is a regional endemic and is designated a Watch Species by BLM in Montana (BLM 1996)

\section{Study Area}

The study area is in southeastern Big Horn County and southwestern Rosebud County, Montana, and is bounded on the west by the Crow Reservation, on the north by the Cheyenne Reservation, on the east by the Custer National Forest and by the Wyoming border to the south (Figures 1, 6, 11). The Tongue River and its drainages comprise the core of the study area.

Tracts of public land managed by the BLM and the State of Montana are interspersed among large areas of private land, with livestock grazing as the dominant land use. Within the survey area, coal mining operations are currently localized in southeastern part of Big Horn County.

Geologically, exposures of the Tertiary Fort Union Formation are found throughout the area. This formation consists of alternating layers of shale, clay siltstone and sandstone, and contains many clinkers (also known as red scoria: baked sandstone and shale) and coal beds. The upper part of the Fort Union Formation is the Tongue River Member, which is the most productive coal-bearing geologic section in Montana (Soil Survey 1996).

Sandy soils generally occur in the higher portions of the landscape, associated with a more weathering resistant caprock; also occurring to a minor extent in elevated positions are thermally altered 
shales and mudstones (forming clinker and scoria). Soils of mid- to lower-slopes are characteristically loams (mostly silt loams), whereas those of the toeslopes, terraces and bottoms are silty, often with a high percentage of clay.

Vegetation in this area is characterized by ponderosa pine woodland, grassland, sagebrush steppe, and barren land on calcareous substrate. Ponderosa pine (Pinus ponderosa) and Rocky Mountain juniper (Juniperus scopulorum) are the only trees present in the uplands, due to the limited rainfall conditions. Canopy cover of trees seldom exceeds $50 \%$ and generally ranges from 10 to $35 \%$. Hardwood forests are extremely limited, with narrow riparian stringers dominated by box elder (Acer negundo); wooded riparian areas may contain plains cottonwood (Populus deltoides) (Carlson and Cooper 2003).

By far the greatest portion of the landscape tends toward dominance by Wyoming big sagebrush (Artemisia tridentata ssp. wyomingensis), the only exception being restricted habitats such as riparian bottoms, ridgeline outcrops. The fact that extensive grasslands can be found over slopes and flats is attributable to past burning of the range, either as a "control" measure or from wildfire. The only other shrub of any consequence is black greasewood (Sarcobatus vermiculatus), which is restricted to alkaline or salt-affected bottomlands and also rarely occurs on sideslopes where appropriate soil conditions exist. Small patches of Nuttall's saltbush (Atriplex gardneri) were found on highly erosive clay outcrops; Dominant associates are few and inconsistent. Rhus trilobata / Pseudoroegneria spicata was also noted as fragmentary occurrences on eroding slope shoulders of sandy knolls and escarpments. Prairie junegrass (Koeleria macrantha) canopy cover is higher than would be expected and has probably increased as a result of intensive grazing pressure on preferred species (Carlson and Cooper 2003).

Common grassland associations include Pascopyrum smithii (Elymus smithii or Agropyron smithii) $\tilde{\boldsymbol{n}}$ Poa secunda, which occurs on fine-textured soils from stream terraces, with soils so heavy that drying cracks are wider than an inch; it also is found on all but the most xeric of upland sites (such as south-facing slopes shoulders, and even here it may occur as a depauperate community). Calamovilfa longifolia $\tilde{n}$ Carex inops ssp. heliophila occurs as small patches or linear extensions on north- or east-facing slopes wtih fine sandy soils. Warmer slopes with comparably sandy soils have a dominant component of bluebunch wheatgrass (Pseudoroegneria spicata or Agropyron spicatum), or Western wheatgrass (Pascopyrum smithii or Agropyron smithii), a common grassland community across the Northern Great Plains. In this area it usually occurs on loamy soils on the upper third of slopes with warm aspects, typically associated with sagebrush sites that had burned in the recent past (Carlson and Cooper 2003).

\section{Methods}

Prior to beginning fieldwork, we identified potential habitat for Astragalus barrii and Physaria didymocarpa var. lanata using USGS topographic maps, soil data (Soil Survey 1996) and information in the MTNHP databases.

For each species, we developed a search image for potential habitat, based on existing information:

A. barrii: Ridge tops, buttes, outcrops, badlands and slopes with sandy clay loam soils or calcareous substrates; vegetation associations of sagebrushgrassland, ponderosa pine and Rocky Mountain juniper, or cushion communities; typically sparsely vegetated areas.

P. didymocarpa var. lanata: Slopes and road cuts with red scoria (clinker) and clay-shale substrates; also calcareous substrates and gravelly, unstable slopes; emphasis on south-facing slopes; sparsely vegetated areas in sagebrush-grassland, mixedshrub, and ponderosa pine communities; near 3800 feet elevation and above. 
While we did not specifically target other Species of Concern, they were opportunistically documented during the course of surveys.

Due to annual temperature and moisture differences, the optimal survey period for Barr's milkvetch and woolly twinpod varies, but is normally late May and early June, when both species are flowering. Surveys in 2001 were delayed, and were conducted between June 18-27. In 2002, surveys were conducted from June 5-14, during the flowering period for both taxa that year.

We began survey work by visiting welldocumented locations to verify that reproductive or vegetative structures were present for positive identification of both taxa. For woolly twinpod, the most diagnostic characteristic is the long, tangled, spreading hairs on the leaves. Although leaf pubescence is sufficient for identification (Fertig 2000), fruit characters are also helpful. For Barr's milkvetch, flowers or their remnants are necessary to distinguish it from co-occurring Astragalus species that have compound leaves with three leaflets and a cushion-forming habit (Heidel \& Marriott 1996). Once we confirmed that diagnostic characteristics could still be observed in the field, surveys were expanded to areas of potential habitat.

Field surveys conducted in 2001 identified one new location for both Barr's milkvetch and several new locations for woolly twinpod. In addition, several other areas were identified as having good potential habitat for one or both of these species. These potential habitat areas formed the primary focus of surveys in 2002 .

Overall, MTNHP botanists walked approximately 25 survey routes in different areas identified as potential habitat. Survey routes are indicated on the 1:24,000 USGS Quad maps in Appendix 2 by solid red lines. Priority was given to potential habitats on the largest tracts of BLM-administered land in the study area, but surveys were also conducted on smaller BLM blokcs, on state land and, where permission was granted, on private land. Access permissions from landowners were documented wherever private land was entered for access or surveys.

For each population of $A$. barrii, $P$. didymocarpa var. lanata, or L. nuttallii visited in the field, we completed an MTNHP Plant Species of Concern Survey form, including documentation of Ecological Rangeland Sites (Natural Resources Conservation Service 2000). Global Positioning System (GPS) coordinates were taken for new locations of the target species. Where appropriate, photographs were taken. Voucher specimens were collected and verified at the Rocky Mountain Herbarium in Laramie, Wyoming, and at the Herbarium at the University of Montana (MONTU).

All data collected on Species of Concern were entered into the MTNHP databases and corresponding spatial coverages.

\section{Results}

Our surveys identified three new locations for Barr's milkvetch, four new locations for woolly twinpod, and two new locations for Nuttall's desert-parsley. Of the 25 routes surveyed, we found new occurrences of globally significant plant species along nine of these routes.

The following speciesí descriptions summarize information available on each species. All occurrences in the study area are listed in Tables 1-3 and mapped in Figures 1, 6, and 11. The identifying numbers in both the Figures and Tables correspond to occurrence numbers assigned in the MTNHP data system. The species descriptions also summarize broader distributional patterns, identifying characteristics, and habitat, including NRCS Rangeland Ecological Sites on which they occur. 


\section{Barr's Milkvetch \\ Astragalus barrii Barneby}

\section{Occurrence in the Study Area}

Figure 1 shows the mapped locations of all Barr's milkvetch occurrences that have been documented in the study area, and Table 1 lists each occurrence. Three new occurrences of Barr's milkvetch were documented in this study (bolded in Table 1), bringing the total for the study area to five. One new population is small, consisting of only four clumps, however the other two are considerably larger, one with more than 200 plants and the other with over 500 individual plants. Population sizes in the state vary widely, ranging from less than 10 to thousands of individuals.

\section{Identification}

Barr's milkvetch forms dense mats (cushions) that rarely exceed $25.9 \mathrm{~cm}$ in height. Prostrate woody stems give rise to numerous leaves, each made up of narrowly elliptic leaflets that are $1-4 \mathrm{~cm}$ long. Both the stems and leaves of $A$. barrii are densely covered with short, white hairs. Iridescent bluish-purple to pinkish-purple flowers arise on short stalks $(7-16 \mathrm{~mm})$ throughout the mats on narrow, open, (1) 2-4 flowered inflorescences. The petals are 7-17 mm long. The calyx is 3-5 $\mathrm{mm}$ long and densely covered with long, white hairs. The sparsely white-hairy pod is narrowly elliptical, 4-8 mm long, and 1-2 mm wide. In Montana, this species blooms from late April to mid-June and later forms narrow, egg-shaped, one- to few-seeded pods. A. barrii may remain in a vegetative condition under stressful conditions.

Barr's milkvetch is distinguished by its small, iridescent, bluish-purple to bluish-pink, early-blooming flowers. Petal color may fade, sometimes to yellowish-white, as flowers dry (Taylor 2001). Flowers are necessary to distinguish $A$. barrii from four other mat-forming, 3-leafleted Astragalus species that overlap geographically with it in Montana: A. aretioides (Sweetwater milkvetch), A. sericoleucus (silky milkvetch), A. gilviflorus (plains milkvetch) and A. hyalinus (summer milkvetch).

A. aretioides and A. sericoleucus have flowers that are typically one-half the size of A. barrii, and tend to grow in denser mats. Both species are known from Big Horn County, but were not encountered during the survey.

A. gilviflorus and A. hyalinus typically have larger, cream to whitish flowers. They also differ from $A$. barrii by having a longer calyx tube $(6-16 \mathrm{~mm})$ and absent or shorter $(<3.5 \mathrm{~mm})$ peduncles (A. barrii: calyx length 2.8-5 mm, peduncle length 7-24 mm). Known in Montana from the Pryor Mountains and from the Ashland District of the Custer National Forest, A. hyalinus is similar in growth habit to A. barrii and is found in similar habitats.

The only similar Astragalus species observed during this survey was A. gilviflorus, which is very abundant in the study area and occurs in the same habitat and locations as $A$. barrii. The majority of $A$. gilviflorus plants were at the end of their blooming period. Vegetatively, A. gilviflorus appears more robust, with longer leaf petioles and larger leaflets than $A$. barrii. The flowers, when present, are distinctly larger than those of $A$. barrii.

\section{Distribution}

Barr's milkvetch is endemic to southwestern South Dakota, northeastern Wyoming and southeastern Montana. A total of 35 occurrences have been documented in Montana: three in Big Horn County (includes one new from this survey), 13 in Rosebud County (includes two new from this survey), 18 in Powder River County, and one in Carter County. 


\section{Habitat}

Habitat data for the three new occurrences of Barr's milkvetch in the study area are consistent with other information for the species (see Table 1). It occurs on heavy clay ("gumbo") knobs, badlands, buttes and barren hilltops, often on calcareous soft shale and siltstone substrates (Heidel \& Marriott 1996). The calcareous clay soils on which A. barrii occurs are likely to be low in organic matter, as these locations are sparsely vegetated (Schassberger 1990). The elevation range is 3,140ñ 4,160 feet.

Barr's milkvetch habitats sometimes have scattered ponderosa pine or Rocky Mountain juniper, but often there is only a sparse shrub cover of big sagebrush and/or shadscale (Atriplex confertifolia). Generally, in southeastern Montana, Barr's milkvetch habitat is dominated by Western wheatgrass (Pascopyrum smithii or Agropyron smithii) thickspike wheatgrass (Elymus lanceolatus or Agropyron dasystachyum), green needlegrass (Nassella viridula or Stipa viridula), little bluestem (Schizachyrium scoparium or Andropogon scoparius), bluebunch wheatgrass (Pseudoroegneria spicata or Agropyron spicatum), prairie junegrass (Koeleria macrantha or Koeleria cristata), native legumes, big sagebrush (Artemisia tridentata), Nuttall's saltbush (Atriplex gardneri) and winterfat (Krascheninnikovia lanata or Ceratoides lanata) (Heidel \& Marriott 1996).

A. barrii grows under harsh edaphic and environmental conditions with limited rainfall and high light intensities. This can limit plant establishment and survival due to high soil water evaporation. Barr's milkvetch often occurs on barren, eroded microsites and may depend on climate to maintain these sites and keep vegetative competition low. At some locations, particularly steep slopes, the soils erode during intense rainstorms. Because of its cushion habit and dense foliage, soil is protected from water erosion beneath $A$. barrii plants, resulting in individuals that are frequently perched atop small pedestals of soil (Heidel \& Marriott 1996).

\section{Rangeland Ecological Sites}

The three new occurrences of $A$. barrii were found on the Badlands (BL) Rangeland Ecological Sites, characterized by hills and knobs that appear more rounded, and have outcrops of shales as a dominant part of the landscape. There is frequently evidence of salts, often occurring around the base of hills and knobs. Very few trees occupy these sites, with the exception of an occasional Rocky Mountain juniper. Vegetation is sparse, and the species present are often typical of clayey sites, but with a greater abundance of shrubs (USDA 2000). 


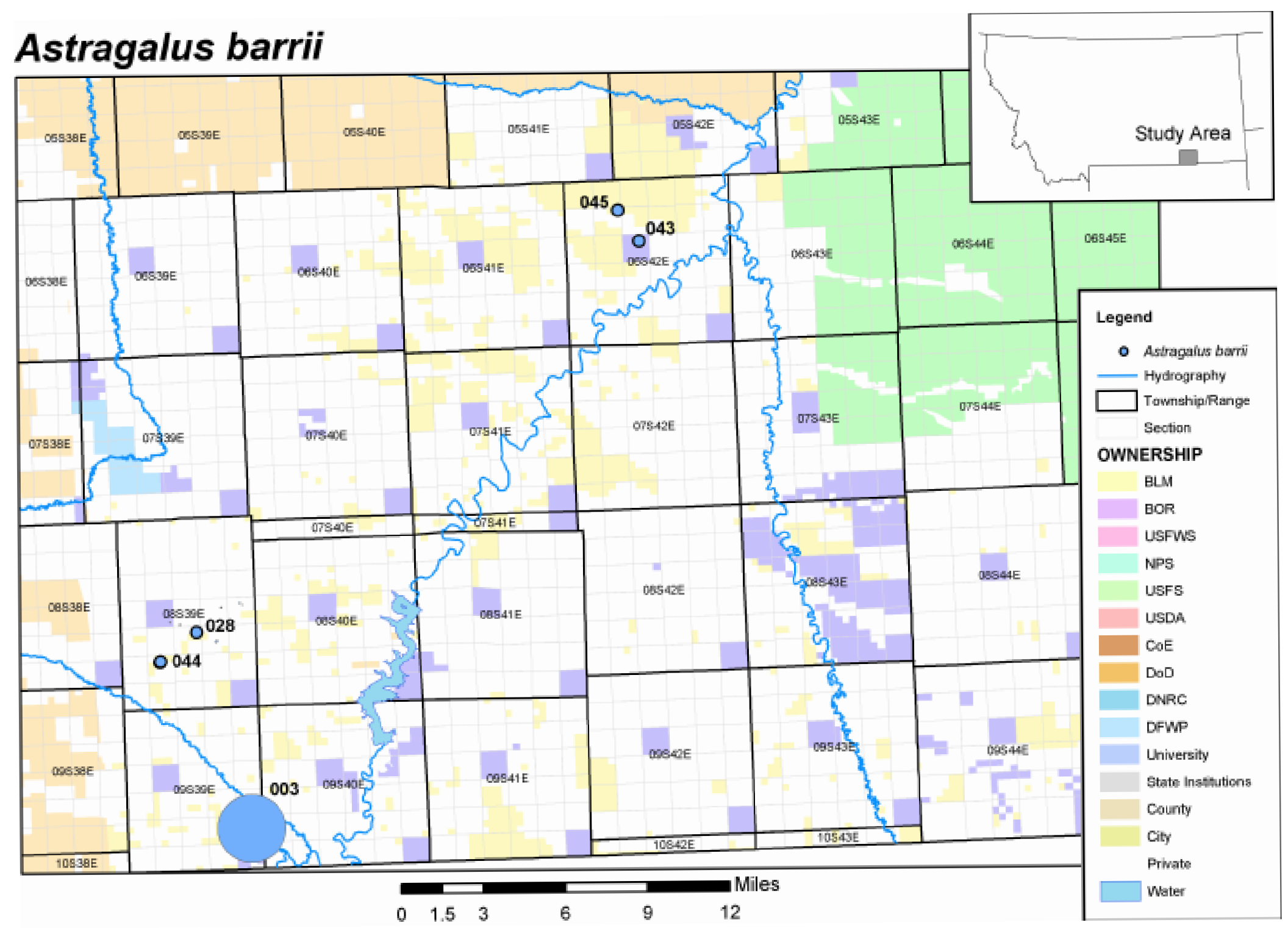

Figure 1. The five occurrence records for Astragalus barrii in the study area. There are three occurrences (including one new occurrence from this study, 044) in southeastern Big Horn County, and two new occurrences (both new from this study, 043, 045) in southwestern Rosebud County. 
Table 1. Element Occurrence (EO) records for Astragalus barrii Barneby in the project study area. Selected descriptive fields are from the Heritage database, with new occurrences highlighted in bold text.

\begin{tabular}{|c|c|c|c|c|c|c|c|c|c|c|c|}
\hline $\begin{array}{c}\text { EO } \\
\text { Number }\end{array}$ & County & Survey Site & Element Occurrence Data & General Description & $\begin{array}{l}\text { Major Land } \\
\text { Resource Area }\end{array}$ & $\begin{array}{l}\text { Rangeland } \\
\text { Ecological Site }\end{array}$ & Latitude & Longitude & $\begin{array}{l}\text { Township } \\
\text { and Range }\end{array}$ & Section & TRS Note \\
\hline 043 & Rosebud & Whitten Creek & $\begin{array}{l}4 \text { major mats/clumps } \\
\text { (approx. } 12 \mathrm{~cm} \text { wide) on } \\
\text { knob. Fruiting with some } \\
\text { remnant flowers. }\end{array}$ & $\begin{array}{l}\text { Hills of red shale, sandstone, and } \\
\text { badlands. NW-facing knob of badlands, } \\
\text { very sparsely vegetated. Associated } \\
\text { species include Sarcobatus vermiculatus, } \\
\text { Pinus ponderosa, Juniperus scopulorum, } \\
\text { Cryptantha sp., Agropyron spicatum; } \\
\text { Astragalus gilviflorus common on same } \\
\text { hills. }\end{array}$ & $\begin{array}{l}\text { Eastern } \\
\text { Sedimentary } \\
\text { Plains, 58AE }\end{array}$ & Badlands (BL) & $451908 \mathrm{~N}$ & $1063519 W$ & 006S042E & 16 & NE4 \\
\hline 044 & Big Horn & $\begin{array}{c}\text { South Fork Spring } \\
\text { Creek / Squirrel } \\
\text { Creek }\end{array}$ & $\begin{array}{l}\text { Over } 500 \text { clumps in two } \\
\text { main clusters still in flower. }\end{array}$ & $\begin{array}{l}\text { Deeply eroded, rounded knobs of } \\
\text { badlands, soft soils of siltly clay. } \\
\text { Sparsely vegetated with } \text { Artemisia } \\
\text { tridentata, Pinus ponderosa, Juniperus } \\
\text { scopulorum, Phlox hoodil, Astragalus } \\
\text { bisulcatus, Agropyron spicatum. }\end{array}$ & $\begin{array}{l}\text { Eastern } \\
\text { Sedimentary } \\
\text { Plains, 58AE }\end{array}$ & Badlands (BL) & $450626 \mathrm{~N}$ & $1065740 \mathrm{~W}$ & 008S039E & 28 & \\
\hline 045 & Rosebud & Whitten Creek & $\begin{array}{l}\text { Over } 200 \text { clumps in two } \\
\text { separate subpopulations, } \\
\text { many still in full flower. }\end{array}$ & $\begin{array}{l}\text { Hills of red siltstone sandstone, and } \\
\text { badlands. NW-and SE-facing slope of } \\
\text { badlands, very sparsely vegetated. } \\
\text { Associated species include Rhus } \\
\text { trilobata Artemisia tridentata, Pinus } \\
\text { ponderosa, Juniperus scopulorum, Phlox } \\
\text { hoodii, Agropyron spicatum; Astragalus } \\
\text { gilviflorus common on same hills. }\end{array}$ & $\begin{array}{l}\text { Eastern } \\
\text { Sedimentary } \\
\text { Plains, 58AE }\end{array}$ & Badlands (BL) & $452009 N$ & $1063614 W$ & 006S042E & $\begin{array}{l}5 \\
8\end{array}$ & $\begin{array}{l}\text { NE4 } \\
\text { NW4 }\end{array}$ \\
\hline 003 & Big Horn & Decker & Common. & $\begin{array}{l}\text { Barren clay soil on ridgetop, with } \\
\text { Haplopappus acaulis and Eriogonum } \\
\text { pauciflorum. }\end{array}$ & & & $450102 \mathrm{~N}$ & $1065349 \mathrm{~W}$ & 009S039E & 25 & NE4 \\
\hline 028 & Big Horn & Spring Creek & $\begin{array}{l}\text { This occurrence contains } 7 \\
\text { subpopulations spread over an } \\
\text { area roughly } 4 \text { miles E-W by } \\
1.5 \text { miles N-S. Each } \\
\text { subpopulation has from } 20 \text { to } \\
1000 \text { plants. }\end{array}$ & $\begin{array}{l}\text { On fine, sandy-clay loam soil, above a } \\
\text { sandstone outcrop, and bare, dry fine soil } \\
\text { or shale, with Artemisia tridentata, } \\
\text { Agropyron spicatum, Phlox hoodii, } \\
\text { Astragalus gilviflorus, Oxytropis sericea, } \\
\text { and Eriogonum sp. }\end{array}$ & & & $450702 \mathrm{~N}$ & $1065501 W$ & $008 \mathrm{~S} 039 \mathrm{E}$ & 23 & $\begin{array}{l}\text { NW4SE4; } \\
15 \text { SW4; } \\
16 \text { SE4; } 22 \\
\text { NE4; } 13 \\
\text { N2; } 14 \\
\text { NE4. }\end{array}$ \\
\hline
\end{tabular}

Bolded records indicate new occurrences documented during this survey. 


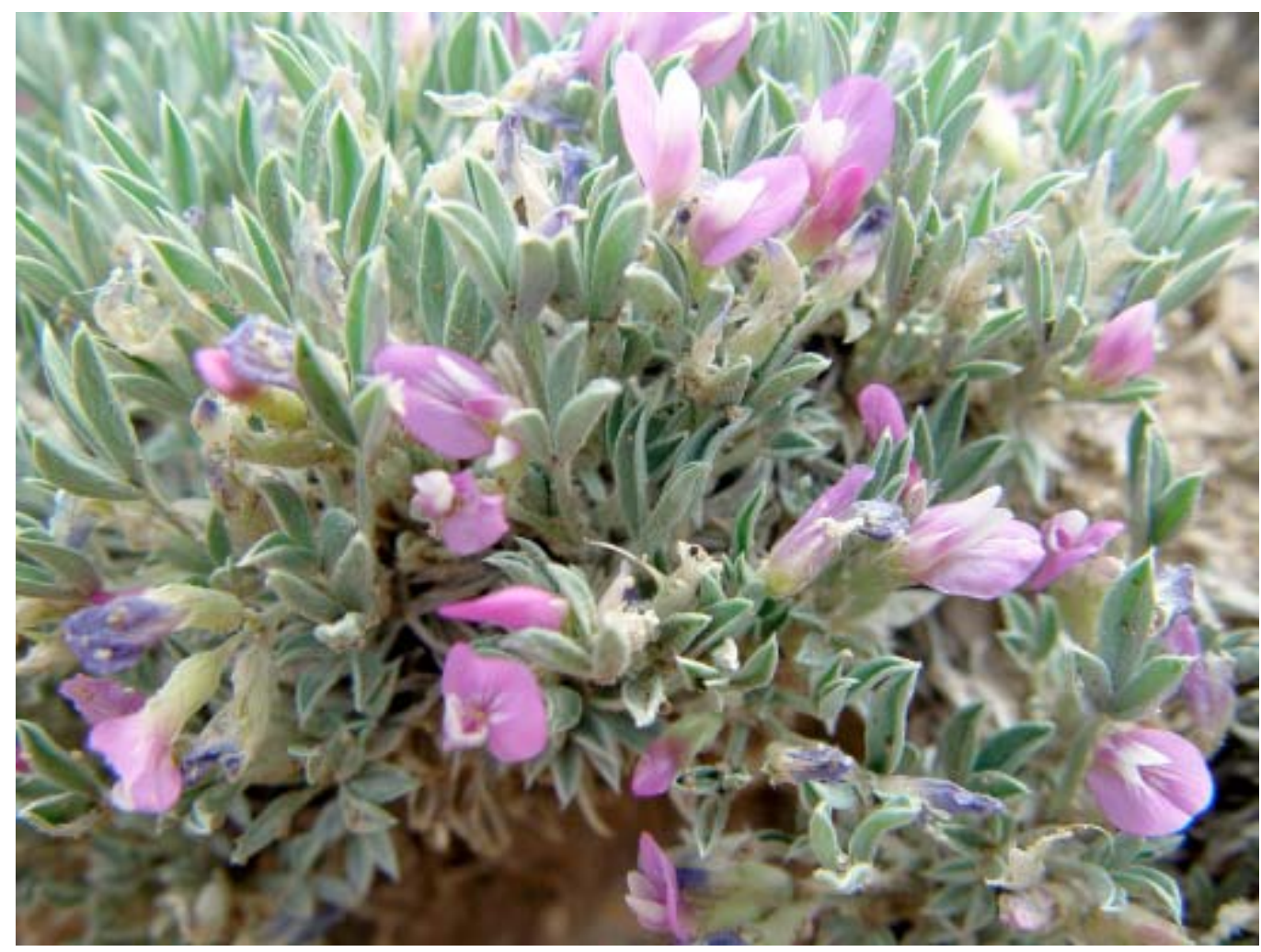

Figure 2. Astragalus barrii close-up. Whitten Creek, Rosebud County.

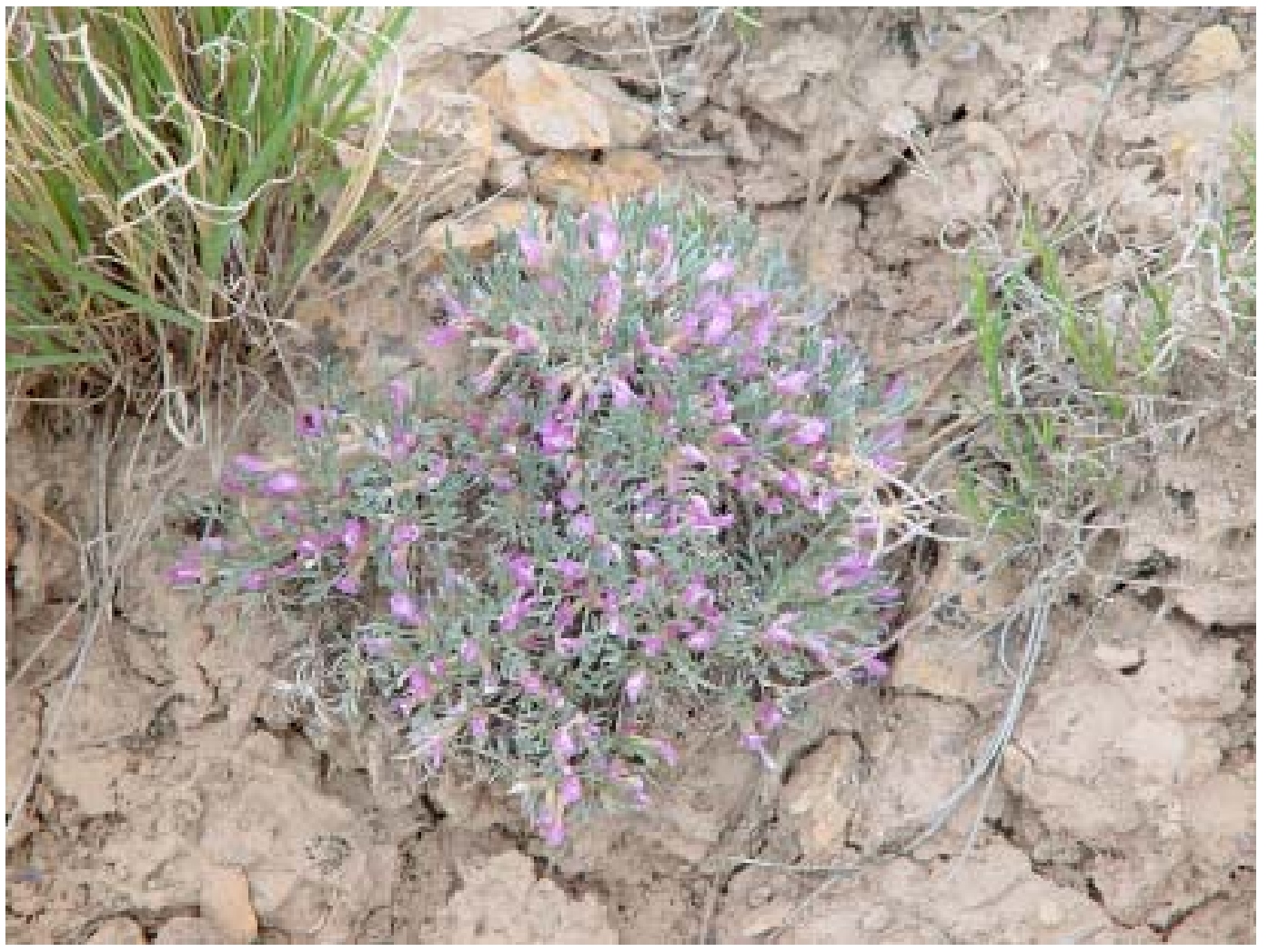

Figure 3. Astragalus barrii plant habit. Whitten Creek, Rosebud County. 


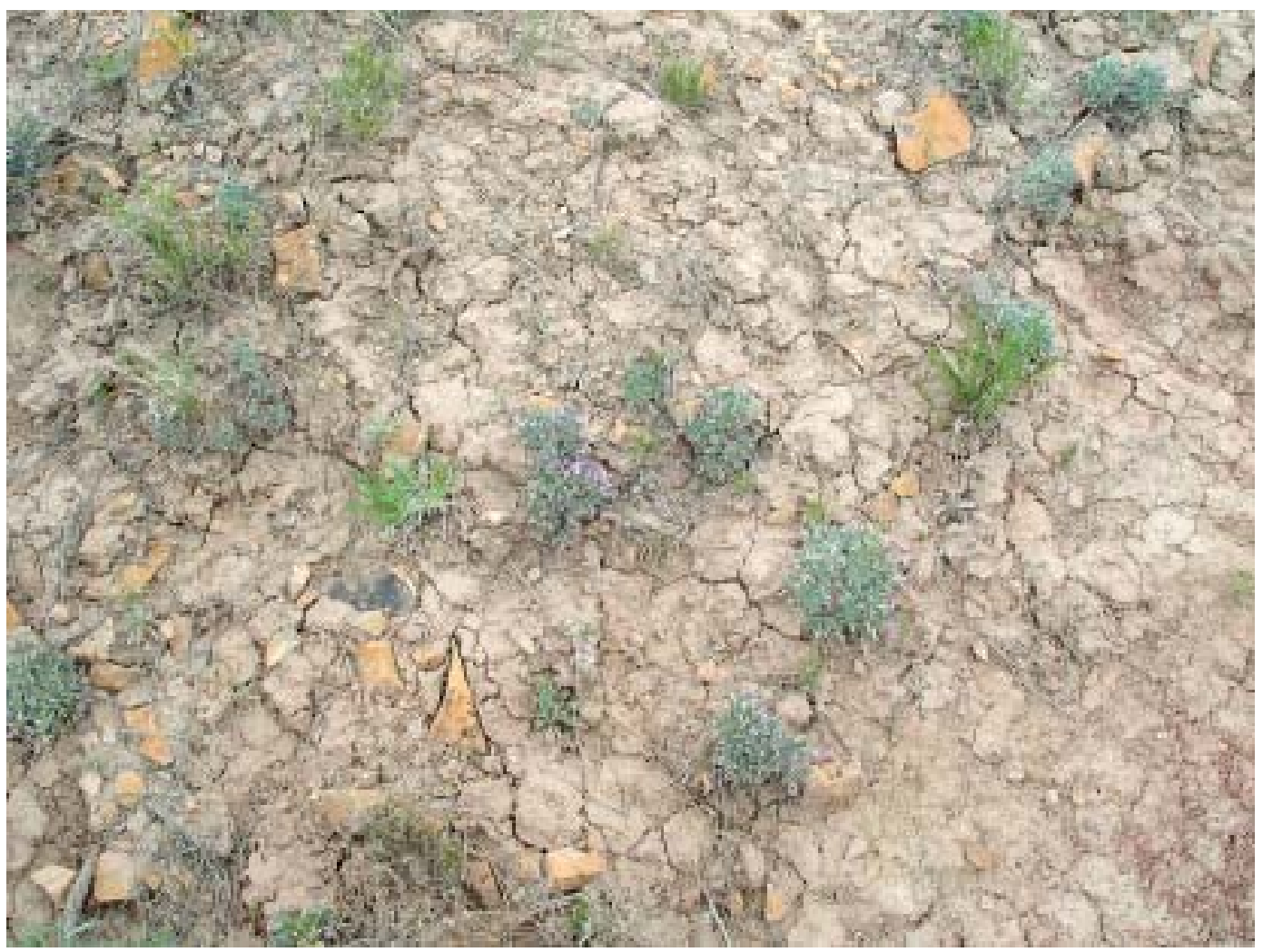

Figure 4. Astragalus barrii habitat. Whitten Creek, Rosebud County.

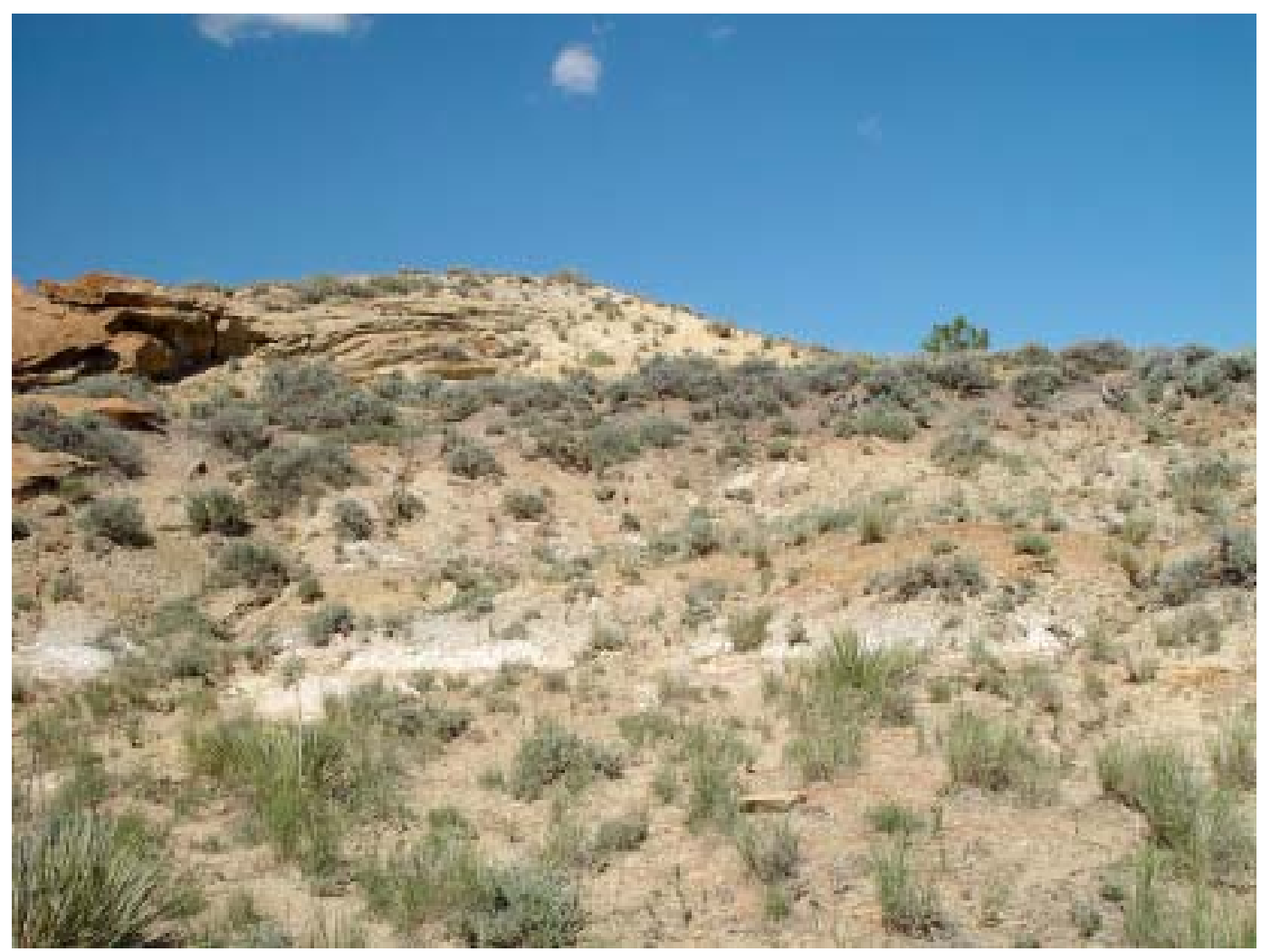

Figure 5. Astragalus barrii habitat. Squirrel Creek, Big Horn County. 


\title{
Woolly Twinpod
}

\author{
Physaria didymocarpa var. lanata A. Nels.
}

\section{Occurrence in the Study Area}

Figure 6 shows the mapped locations of all woolly twinpod occurrences that have been documented in the study area, and Table 2 lists each occurrence. Four new occurrences were documented in this study (boldd in Table 2) bringing the total number for the study area to five. Population sizes for all woolly twinpod occurrences in the area range from 16 plants to thousands of individuals.

\section{Identification}

Woolly twinpod is a tufted, multi-stemmed perennial herb covered with long-stalked, tangled, multibranched woolly hairs (giving the entire plant a gray appearance). Basal leaves are entire to coarsely dentate and shaggy-margined due to the long-stalked pubescence. Stem leaves are shorter, oblanceolate, and 1-2 cm long. The inflorescence consists of a congested cluster of yellow, 4-petaled flowers 8-12 mm long. Mature fruits appear as two inflated, balloon-like pods with shaggy pubescence. The replum of the mature fruit is narrowly lance-shaped to oblanceolate with 2 stubby funiculi (stalks connecting ovule to placenta) per face. Flowers are borne from May-June, with fruits produced as late as September (Fertig 2000).

Many similar Physaria species exist in Montana, and a microscope or hand lens, technical keys and reference to herbarium specimens are recommended for positive identification. P. didymocarpa var. lanata is distinguished by leaf pubescence, having long, tangled, spreading hairs, especially evident at leaf bases. In contrast, $P$. didymocarpa var. didymocarpa (common twinpod), has appressed hairs on the basal leaves giving them a smooth look (Figure 10), and there are mostly 3-6 ovules/funiculi per locule. $P$. acutifolia (sharp-leaf twinpod) also has leaves with appressed hairs.

P. brassicoides (double twinpod) is the most similar to woolly twinpod, and grows in eastern Montana on clay hills and road cuts. However, double twinpod has appressed leaf hairs and a narrowly linear fruit partition, whereas woolly twinpod has shaggy hairs and narrowly lanceolate to oblanceolate partitions (Dorn 1992; Fertig 2000).

\section{Distribution}

Woolly twinpod is a regional endemic, restricted to north-central Wyoming and southeastern Montana. Five occurrences have been documented in Montana ñ two in Big Horn County (includes one new from this survey) and three in Rosebud County (all new from this survey).

\section{Habitat}

Habitat information for woolly twinpod in the study area has been greatly improved with the discovery of four more occurrences. Habitat summaries are provided in Table 2. It occurs on sandstone outcrops, redbed clay (clinker or scoria)-shale slopes, calcareous substrates, and road cuts, where it occupies open, shrub-dominated slopes, sometimes with a sparse cover of ponderosa pine and Rocky Mountain juniper. Common associates include ponderosa pine, Rocky Mountain juniper, fragrant sumac (Rhus trilobata), big sagebrush, bluebunch wheatgrass, and needle-and-thread grass (Hesperostipa comata or Stipa comata). Elevation varies from 3300 to 4100 feet.

\section{Rangeland Ecological Sites}

The four new occurrences of $P$. didymocarpa var. lanata were found on Coarse Clay (CC), Badlands (BL) and Thin Breaks (TB) Rangeland Ecological Sites. Coarse Clay (CC) Rangeland Ecological Sites occur on undulating to rolling uplands, fans, foot slopes and low ridges. Coarse Clay sites are normally 
located on unstable landscapes of slumping shales, commonly with hummocky or dune-like topography. These sites have soils with less than 10 inches to hard bedrock.

Badlands (BL) Rangeland Ecological Sites are characterized by hills and knobs that appear more rounded, and have outcrops of shales as a dominant part of the landscape. There is frequently evidence of salts, often occurring around the base of hills and knobs. Very few trees occupy these sites, with the exception of an occasional Rocky Mountain juniper. Vegetation is sparse, and the species present are often typical of clayey sites, but with a greater abundance of shrubs.

Thin Breaks (TB) Rangeland Ecological Sites are characterized by a landscape that has steep to very steep, angular and rough topography, with the tops of these sites appearing somewhat level. Outcrops of sandstone, siltstone or other hard rock dominate parts of the site. There are numerous ledges where an occasional tree occurs. The majority of vegetation is generally typical of sandy or silty sites, but with more shrubs (USDA 2000). 


\section{Physaria didymocarpa var. lanata}

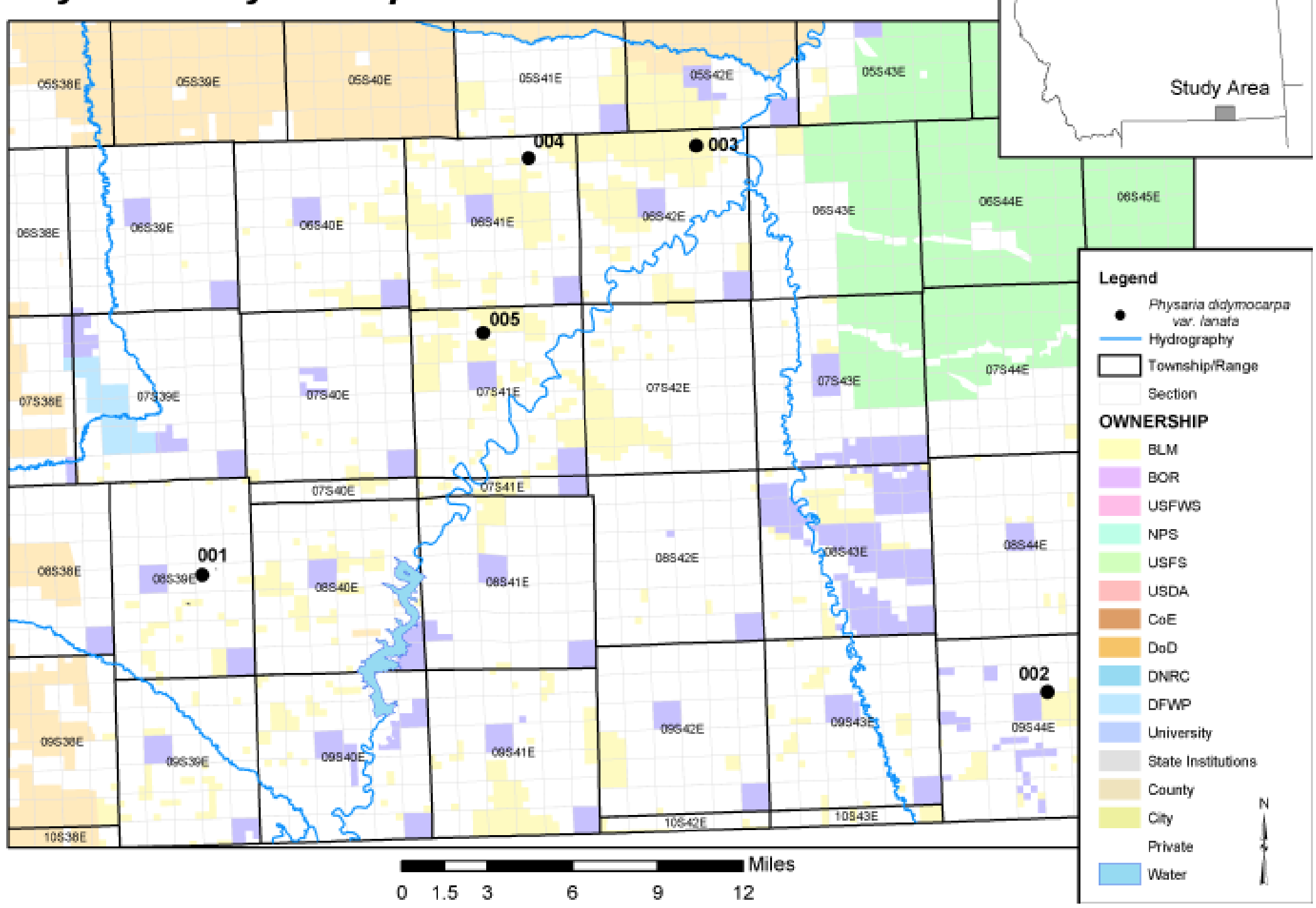

Figure 2. The five occurrence records for Physaria didymocarpa var. lanata in the study area. There are two occurrences (including one new occurrence from this study, 002) in southeastern Big Horn County, and three new occurrences (all new from this study, 003-005) in southwestern Rosebud County. 
Table 2. Element Occurrence (EO) records for Physaria didymocarpa var. lanata A. Nels. in the project study area. Selected descriptive fields are from the Heritage database, with new occurrences highlighted in bold text.

\begin{tabular}{|c|c|c|c|c|c|c|c|c|c|c|c|}
\hline $\begin{array}{c}\text { EO } \\
\text { Number }\end{array}$ & County & Survey Site & Element Occurrence Data & General Description & $\begin{array}{l}\text { Major Land } \\
\text { Resource Area }\end{array}$ & $\begin{array}{c}\text { Rangeland } \\
\text { Ecological Site }\end{array}$ & Latitude & Longitude & $\begin{array}{l}\text { Township } \\
\text { and Range }\end{array}$ & Section & TRS Note \\
\hline 002 & Big Horn & Tidwell Draw & $\begin{array}{l}\text { Over } 100 \text { individuals covering } \\
\text { entire south-facing exposure; } \\
95 \% \text { fruiting; }<5 \% \text { vegetative. } \\
5 \text { or } 6 \text { large individuals ( }>20 \\
\text { cm wide with fruits). }\end{array}$ & $\begin{array}{l}\text { Steep, sandy, south-facing slope } \\
\text { above draw with sandstone outcrops } \\
\text { and fragments; fairly productive } \\
\text { slope - high grass cover. Shrubs and } \\
\text { grass community with an occasional } \\
\text { Juniperus scopulorum or Pinus } \\
\text { ponderosa. Grasses dominate: Stipa } \\
\text { comata, } \text { Agropyron spicatum, Bromus } \\
\text { japonicus. Shrubs and forbs: } \text { Rhus } \\
\text { trilobata, Artemisia tridentata, } \\
\text { Ceratoides lanata, } \text { Astragalus } \\
\text { gilviflorus, Yucca glauca, Opuntia } \\
\text { polyacantha. }\end{array}$ & $\begin{array}{c}\text { Eastern } \\
\text { Sedimentary } \\
\text { Plains, 58AE }\end{array}$ & $\begin{array}{l}\text { Thin Breaks } \\
\text { (TB) }\end{array}$ & $450330 \mathrm{~N}$ & $1061909 w$ & $009 \mathrm{~S} 044 \mathrm{E}$ & 15 & $\begin{array}{l}\text { NW4; } 10 \\
\text { SE4SW4 }\end{array}$ \\
\hline 003 & Rosebud & Zook Creek & $\begin{array}{l}\text { Approximately } 50 \text { individuals; } \\
20 \% \text { fruiting, } 80 \% \text { vegetative } \\
\text { (basal rosettes only). Doesn't } \\
\text { occur in areas of slope that are } \\
\text { significantly composed of red } \\
\text { shale. }\end{array}$ & $\begin{array}{l}\text { Southwest-facing slope of redbed } \\
\text { shale and sand east of creek. Red } \\
\text { shale and sand slope below sandstone } \\
\text { outcrop. Moderately steep slope. } \\
\text { Open slope of Pinus ponderosa and } \\
\text { Juniperus scopulorum; bunch grasses } \\
\text { and shrubs also common. Associated } \\
\text { species include trees: Pinus } \\
\text { ponderosa, Juniperus scopulorum; } \\
\text { shrubs: Yucca glauca, Rhus trilobata, } \\
\text { Atriplex confertifolia; grasses: } \\
\text { Agropyron spicatum, Stipa comata, } \\
\text { Bouteloua curtipendula; forbs: Gaura } \\
\text { coccinea, Sphaeralcea coccinea, } \\
\text { Psoralea sp. }\end{array}$ & $\begin{array}{c}\text { Eastern } \\
\text { Sedimentary } \\
\text { Plains, 58AE }\end{array}$ & $\begin{array}{l}\text { Coarse Clay } \\
\text { (CC) }\end{array}$ & $452032 N$ & $1063325 W$ & $006 \mathrm{~S} 042 \mathrm{E}$ & 2 & $\begin{array}{l}\text { NW4SW4; } 3 \\
\text { NE4NW4 }\end{array}$ \\
\hline
\end{tabular}




\begin{tabular}{|c|c|c|c|c|c|c|c|c|c|c|c|}
\hline $\begin{array}{c}\text { EO } \\
\text { Number }\end{array}$ & County & Survey Site & Element Occurrence Data & General Description & $\begin{array}{l}\text { Major Land } \\
\text { Resource Area }\end{array}$ & $\begin{array}{c}\text { Rangeland } \\
\text { Ecological Site }\end{array}$ & Latitude & Longitude & $\begin{array}{l}\text { Township } \\
\text { and Range }\end{array}$ & Section & TRS Note \\
\hline 004 & Rosebud & Bull Creek & $\begin{array}{l}\text { Fairly abundant; } 16 \\
\text { individuals in one area, } \\
\text { occupying approx. } 20 \text { square } \\
\text { feet. }\end{array}$ & $\begin{array}{l}\text { Sandy, rocky, southwest-facing slope } \\
\text { of roadcut, clinker-shale mix, } \\
\text { sparsely vegetated. Southwest-facing } \\
\text { slope adjacent to 2-track road. Loose, } \\
\text { sandy shale. Dominated by grasses; } \\
\text { interspersed with } \text { Rhus trilobata and } \\
\text { Artemisia cana. Associated species } \\
\text { include } \text { Agropyron spicatum, } \\
\text { Artemisia cana, Artemisia frigida, } \\
\text { Rhus trilobata, and Eriogonum sp. }\end{array}$ & $\begin{array}{c}\text { Eastern } \\
\text { Sedimentary } \\
\text { Plains, 58AE }\end{array}$ & $\begin{array}{l}\text { Coarse Clay } \\
\text { (CC) }\end{array}$ & $452025 \mathrm{~N}$ & $1064042 W$ & 006S041E & 2 & S2SW4 \\
\hline 005 & Rosebud & Canyon Creek & $\begin{array}{l}19 \text { individuals occuping } \\
\text { approx. } 100 \text { square yards. } \\
95 \% \text { fruiting, } 5 \% \text { vegetative. }\end{array}$ & $\begin{array}{l}\text { Generally barren sandstone } \\
\text { outerops; calcium carbonate present; } \\
\text { south-facing slope. Juniperus } \\
\text { scopulorum on the slope above. } \\
\text { Slopes are shrub dominated with } \\
\text { Chrysothamnus nauseosus, Artemisia } \\
\text { cana, Rhus trilobata. Agropyron } \\
\text { spicatum also present. }\end{array}$ & $\begin{array}{l}\text { Eastern } \\
\text { Sedimentary } \\
\text { Plains, 58AE }\end{array}$ & Badlands (BL) & $451508 \mathrm{~N}$ & $1064256 \mathrm{~W}$ & $007 \mathrm{~S} 041 \mathrm{E}$ & 9 & NW4NE4 \\
\hline 001 & Big Horn & Spring Creek & $\begin{array}{l}\text { 2001: locally abundant; } 90 \% \\
\text { flowering, } 10 \% \text { basal rosette } \\
\text { only. Size of occupied area is } \\
\text { similar to } 1993 \text { estimate. } 1993 \text { : } \\
\text { flowering mostly in May, but a } \\
\text { few plants still flowering in } \\
\text { August. Locally abundant, } 1000- \\
2000 \text { plants. }\end{array}$ & $\begin{array}{l}\text { 1993: "scoria" and sometimes shale } \\
\text { substrate. } 2001 \text { : steep southwest-facing } \\
\text { slope of red scoria and shale substrate; } \\
\text { hills rise from Spring Creek } \\
\text { bottomland. Characteristic associated } \\
\text { species include Stipa comata, } \\
\text { Agropyron spicatum, Oryzopsis } \\
\text { hymenoides, Phlox hoodii. Other } \\
\text { common species include: Chaenactis } \\
\text { douglasii, Sphaeralcea coccinea. }\end{array}$ & & & $450804 \mathrm{~N}$ & $1065533 \mathrm{~W}$ & $008 \mathrm{~S} 039 \mathrm{E}$ & 14 & $\mathrm{~N} 2 ; 22 \mathrm{E} 2$ \\
\hline
\end{tabular}

Bolded records indicate new occurrences documented during this survey. 


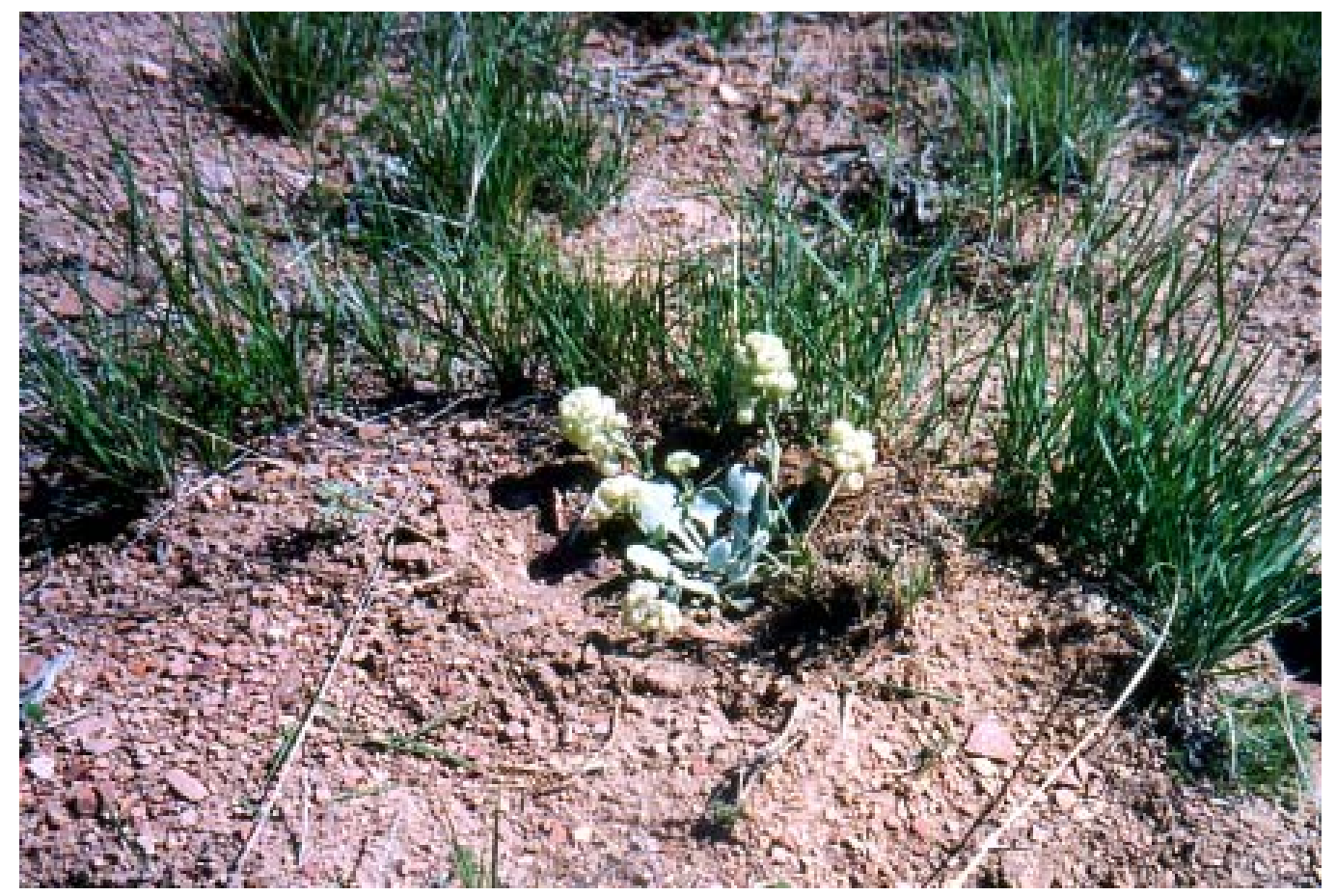

Figure 7. Physaria didymocarpa var. lanata; fruiting plant habit. Spring Creek, Big Horn County.

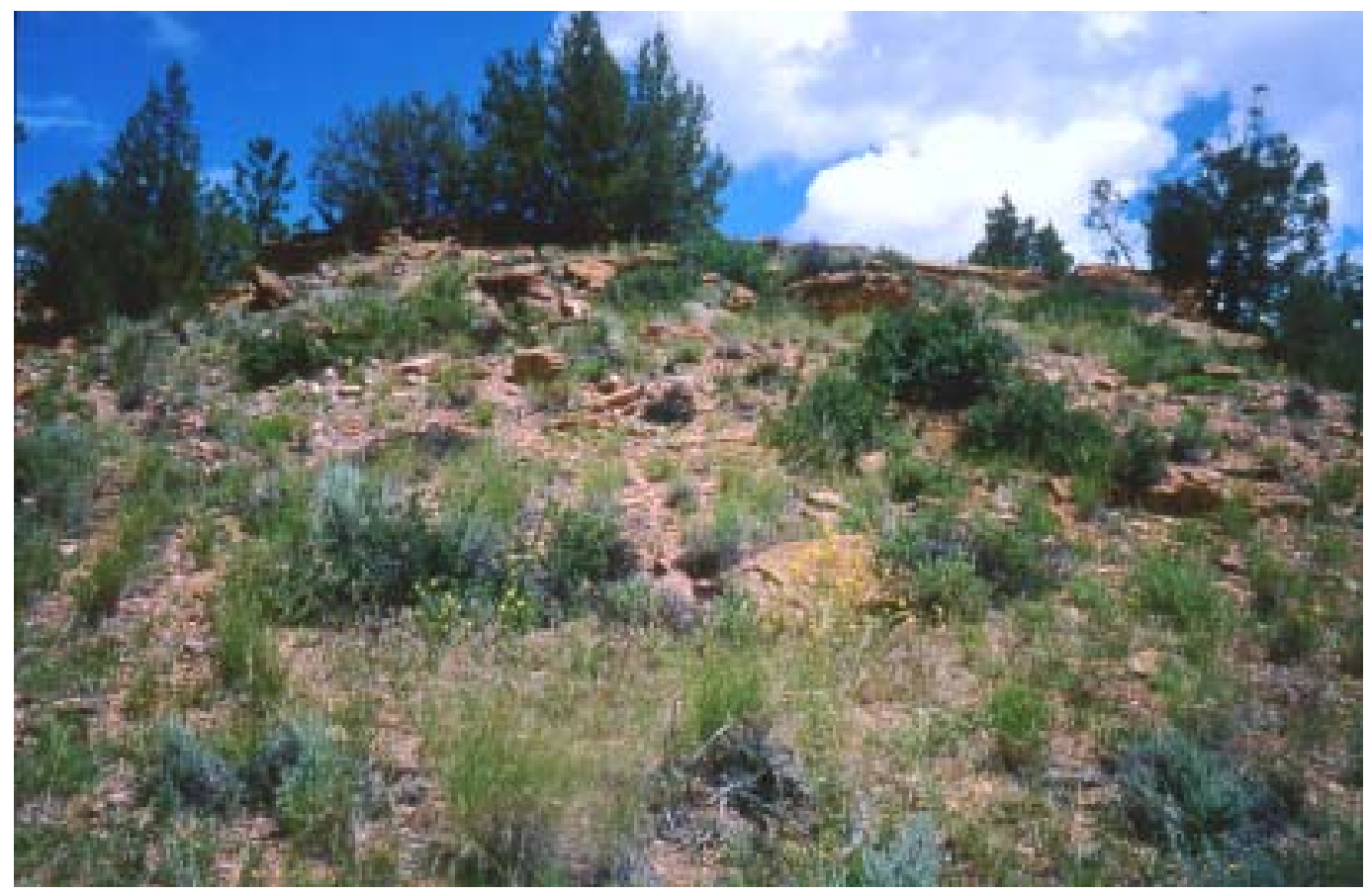

Figure 8. Physaria didymocarpa var. lanata habitat. Zook Creek, Rosebud County. 


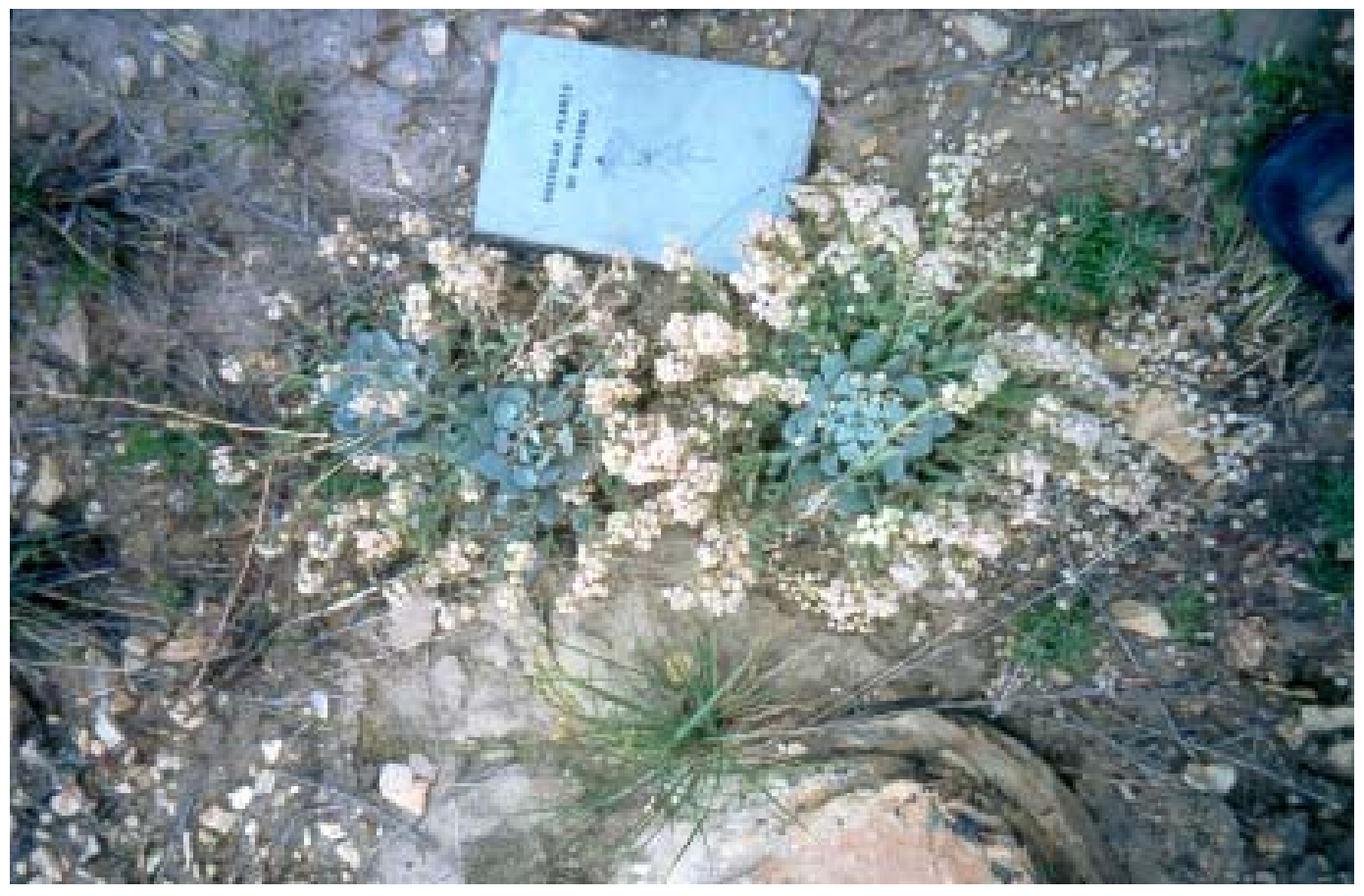

Figure 9. Physaria didymocarpa var. lanata plant with fruits. Tidwell Draw, Big Horn County.

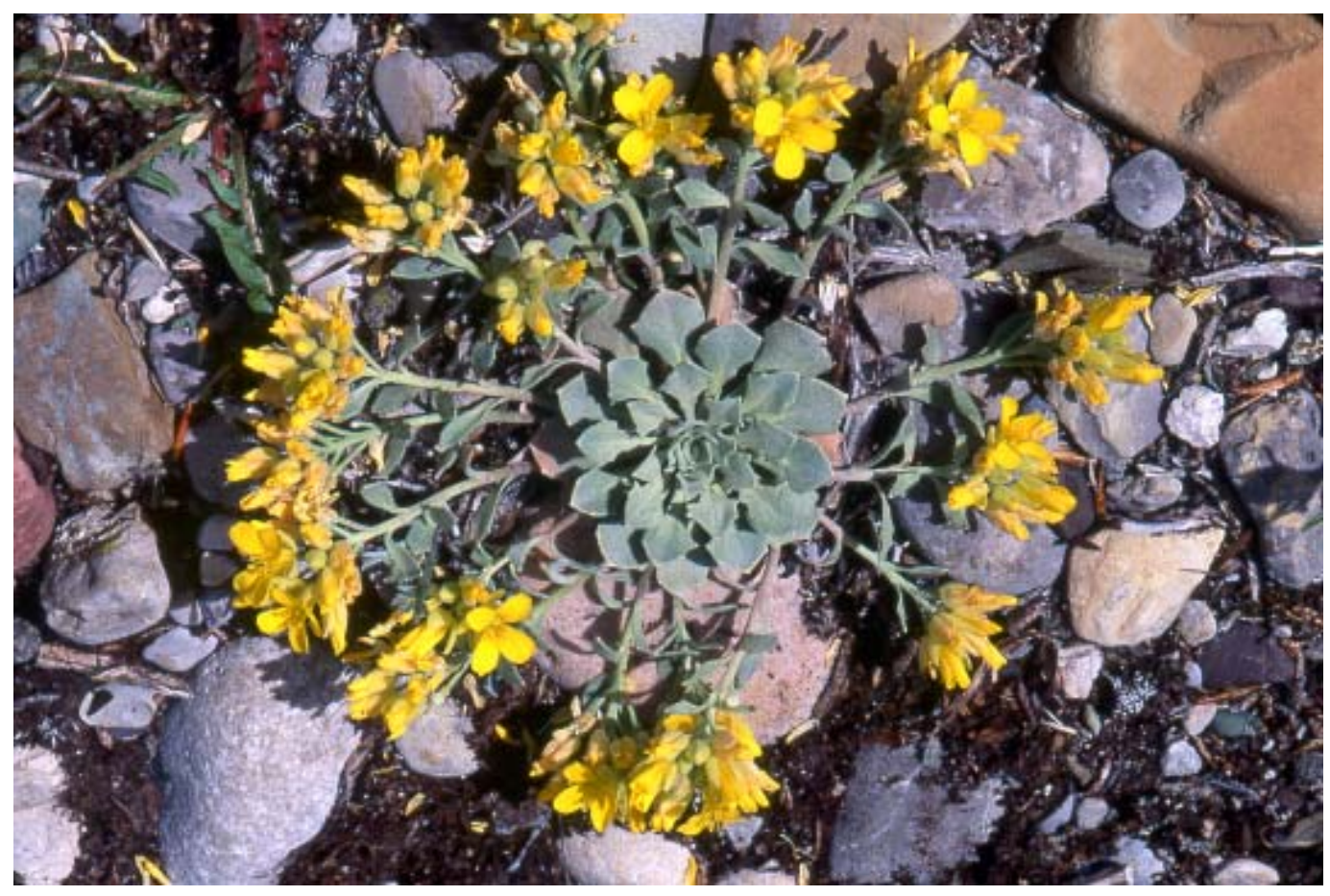

Figure 10. Physaria didymocarpa var. didymocarpa plant in flower. This variety looks similar but appears smoother look and lacks the long hairs of variety lanata. 


\section{Nuttall's desert-parsley \\ Lomatium nuttallii (Gray) J.F. Macbr.}

\section{Occurrence in the Study Area}

Figure 11 shows the three mapped locations of Nuttall's desert-parsley documented in the study area, and Table 3 lists each occurrence. Of the two newly discovered populations (bold printed in Table 3), one has over 300 individual plants, while the other is considerable smaller, with only 30 plants observed.

\section{Identification}

L. nuttallii is an upright perennial herb that reaches a height of 1-4 dm tall. These plants are glabrous, yellow-green in color and have a pleasant, aromatic scent. The basal leaves are once or twice pinnately compound or three-parted. The leaf blades are 2-15 cm long with ultimate linear divisions that are 1-2 $\mathrm{mm}$ wide and some greater than $1 \mathrm{~cm}$ long. The leaves arise from a thickened rootstock that is covered with old leaf bases. The leaf petioles are expanded and sheathed at the base. Several to many small flowers are borne in flat-topped, compound umbels on stout, leafless flower stems that are generally taller than the leaves. Involucels of united or separate linear segments subtend the umbellets and often protrude beyond the flowers. Flowers have 5 petals and 5 stamens attached above a single, two-chambered pistil with two styles. The mature fruits are flattened and narrowly oval-shaped with marginal wings and low ribs on the flat faces; they are 5-9 mm long and 3-4 mm wide. Fruiting pedicels are mostly 1-2 mm long. Flowering is usually in June, with fruits produced by July.

Mature fruits and the leaf arrangement are distinctive features used to separate this species from similar Lomatium species. Key characteristics are its non-lacy leaves, the persistence of the old leaves at the base of the plant, lack of hairs, and relatively small fruits. Two similar species of Lomatium occur in Montana: L. triternatum (nine-leaf lomatium), which is likely to occur within the study area, is normally somewhat hairy and has triternate leaves, some of which are on the flowering stem; L. ambiguum (streambank desert-parsley), a more western species, also has leaves on the flowering stem and lacks involucels. Another similar species known from Wyoming but not yet documented in Montana, $L$. graveolens (king desert-parsley) is very similar and is best separated by the larger fruits (10-13 $\mathrm{mm}$ ), longer fruiting pedicels $(2-7 \mathrm{~mm})$, and a smell that is notably malodorous.

\section{Distribution}

Lomatium nuttallii is a regional endemic. It is most abundant in central Wyoming, with at least one occurrence in Colorado, and a few occurrences in Nebraska. It was historically reported from South Dakota but is thought to be extirpated in that state. In Montana, it is known only from three locations: two in Big Horn County (one new from this survey) and one in Rosebud County (new from this survey).

\section{Habitat}

The two new occurrences of Nuttall's desert-parsley provide additional data on this speciesí habitat in Montana. Nuttall's desert-parsley grows on open, rocky slopes of sandstone, siltstone or clayey shale, in open pine woodlands. The vegetation is generally sparse, and commonly includes ponderosa pine, Rocky Mountain juniper, bluebunch wheatgrass, Western wheatgrass, big sagebrush, and rubber-rabbitbrush (Ericameria nauseosa or Chrysothamnus nauseosus). Elevation ranges from 3400 to 7200 feet.

\section{Rangeland Ecological Sites}

Of the L. nuttallii occurrences, one was found in a Thin Breaks (TB) Rangeland Ecological Site and the other in an area that keyed to an Overflow (OV) site. This location is in a very dry creek bottom adjacent to an ephemeral stream. The associated vegetation was more abundant and diverse than the surrounding 
uplands. Some of the trees were green ash (Fraxinus pennsylvanica), with Rocky Mountain juniper and ponderosa pine also abundant.

Overflow (OV) Rangeland Ecological Sites are located adjacent to ephemeral streams, with the water table not present within 3.5 feet of the soil surface. Vegetation is obviously different from the adjacent uplands. Thin Breaks (TB) Rangeland Ecological Sites are characterized by a landscape that has steep to very steep, angular and rough topography, with the tops of these sites appearing somewhat level. Outcrops of sandstone, siltstone or other hard rock dominate parts of the site. There are numerous ledges where an occasional tree occurs. The majority of vegetation is generally typical of sandy or silty sites, but with more shrubs (USDA 2000). 


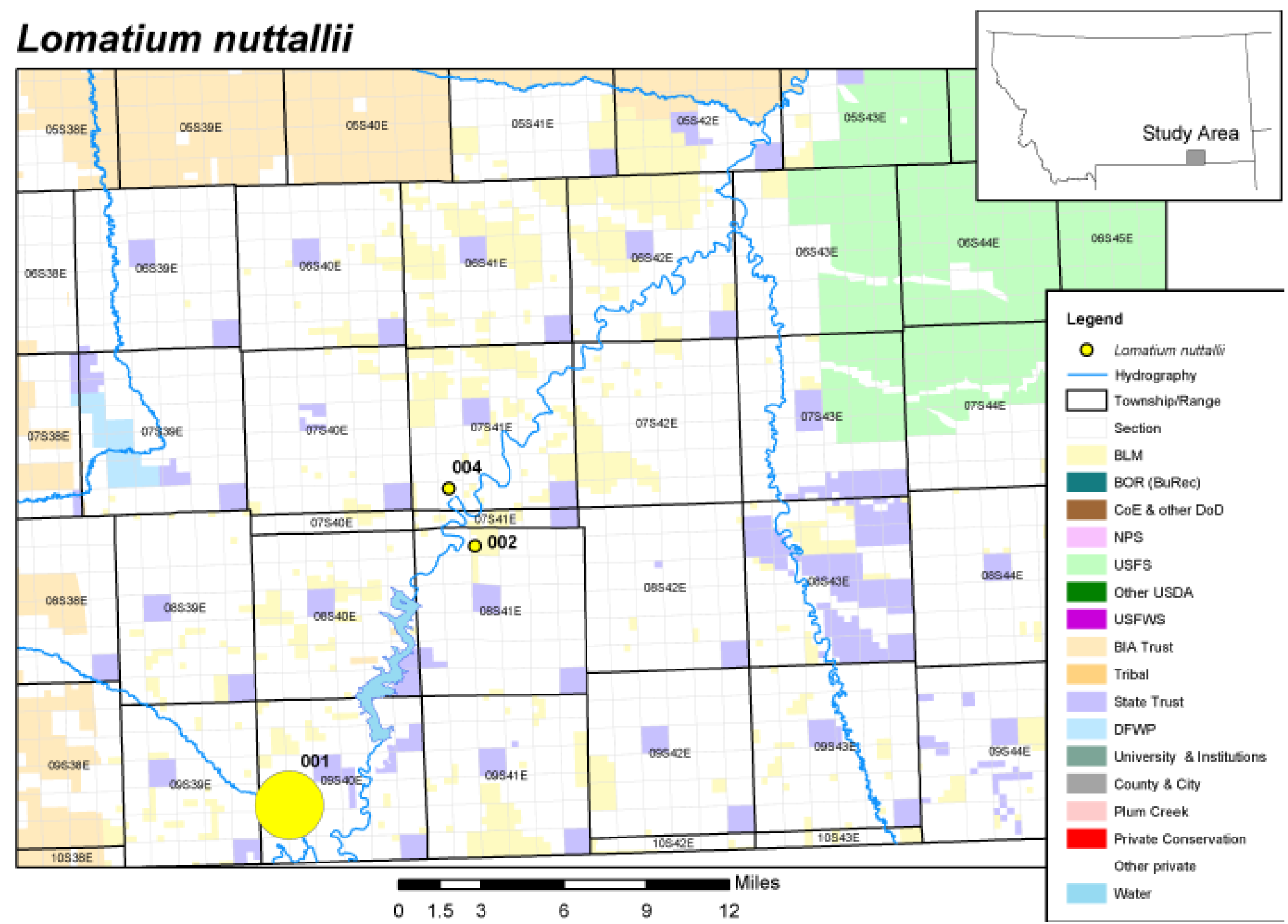

Figure 3. The three occurrence records for Lomatium nuttallii in the study area. There are two occurrences (including one new occurrence from this study, 002) in southeastern Big Horn County, and one new occurrence (new from this study, 044) in southwestern Rosebud County. 
Table 3. Element Occurrence (EO) records for Lomatium nuttallii (Gray) J.F.Macbr. in the project study area. Selected descriptive fields are from the Heritage database, with new occurrences highlighted in bold text.

\begin{tabular}{|c|c|c|c|c|c|c|c|c|c|c|c|}
\hline $\begin{array}{c}\text { EO } \\
\text { Number }\end{array}$ & County & Survey Site & Element Occurrence Data & General Description & $\begin{array}{l}\text { Major Land } \\
\text { Resource Area }\end{array}$ & $\begin{array}{l}\text { Rangeland } \\
\text { Ecological Site }\end{array}$ & Latitude & Longitude & $\begin{array}{l}\text { Township } \\
\text { and Range }\end{array}$ & Section & TRS Note \\
\hline 002 & Rosebud & Tongue River & $\begin{array}{l}\text { Over } 300 \text { individual clusters, } \\
\text { in } 2 \text { separate groups. In late } \\
\text { fower and early fruit. }\end{array}$ & $\begin{array}{l}\text { Steep, rocky, southwest- and } \\
\text { northeast-facing slope above draw, } \\
\text { siltstone outcrops and rock } \\
\text { fragments covering the surface. } \\
\text { Sparce vegetation with a dense } \\
\text { Juniperus scopulorum and Pinus } \\
\text { ponderosa cover close by. } \\
\text { Juniperus scopulorum, Pinus } \\
\text { ponderosa, Agropyron spicatum, } \\
\text { Cryptantha celosioides, Lesquerella } \\
\text { alpina, and Haplopappus acaulis } \\
\text { are common associates. }\end{array}$ & $\begin{array}{c}\text { Eastern } \\
\text { Sedimentary } \\
\text { Plains, 58AE }\end{array}$ & $\begin{array}{c}\text { Thin Breaks } \\
\text { (TB) }\end{array}$ & $450935 \mathrm{~N}$ & $1064319 \mathrm{~W}$ & 007S041E & 32 & $\mathrm{NC}$ \\
\hline 003 & Big Horn & Tongue River & $\begin{array}{l}\text { Approximately } 30 \text { individuals. } \\
\text { In late flower and early fruit. }\end{array}$ & $\begin{array}{l}\text { Northern aspect of a dry drainage } \\
\text { bottom. A wide spot in the channel } \\
\text { with substantial tree cover. } \\
\text { Fraxinus pennsylvanica, Juniperus } \\
\text { scopulorum, Agropyron smithil, } \\
\text { Symphoricarpos occidentalis, } \\
\text { Toxicodendron rydbergii. }\end{array}$ & $\begin{array}{c}\text { Eastern } \\
\text { Sedimentary } \\
\text { Plains, 58AE }\end{array}$ & Overflow (OV) & $451225 \mathrm{~N}$ & $1064424 W$ & 008S041E & 4 & SW4 \\
\hline 001 & Big Horn & Squirrel Creek & No information provided. & $\begin{array}{l}\text { First collection in Montana. On } \\
\text { shallow, rocky soil of a sandstone } \\
\text { cliff. Associates include Agropyron } \\
\text { spicatum, Pinus ponderosa and } \\
\text { Juniperus scopulorum. }\end{array}$ & $\begin{array}{l}\text { Eastern } \\
\text { Sedimentary } \\
\text { Plains, 58AE }\end{array}$ & Thin Breaks (TB) & $450135 \mathrm{~N}$ & $1065159 \mathrm{~W}$ & $008 \mathrm{~S} 040 \mathrm{E}$ & 20 & SW4 \\
\hline
\end{tabular}

Bolded records indicate new occurrences documented during this survey. 


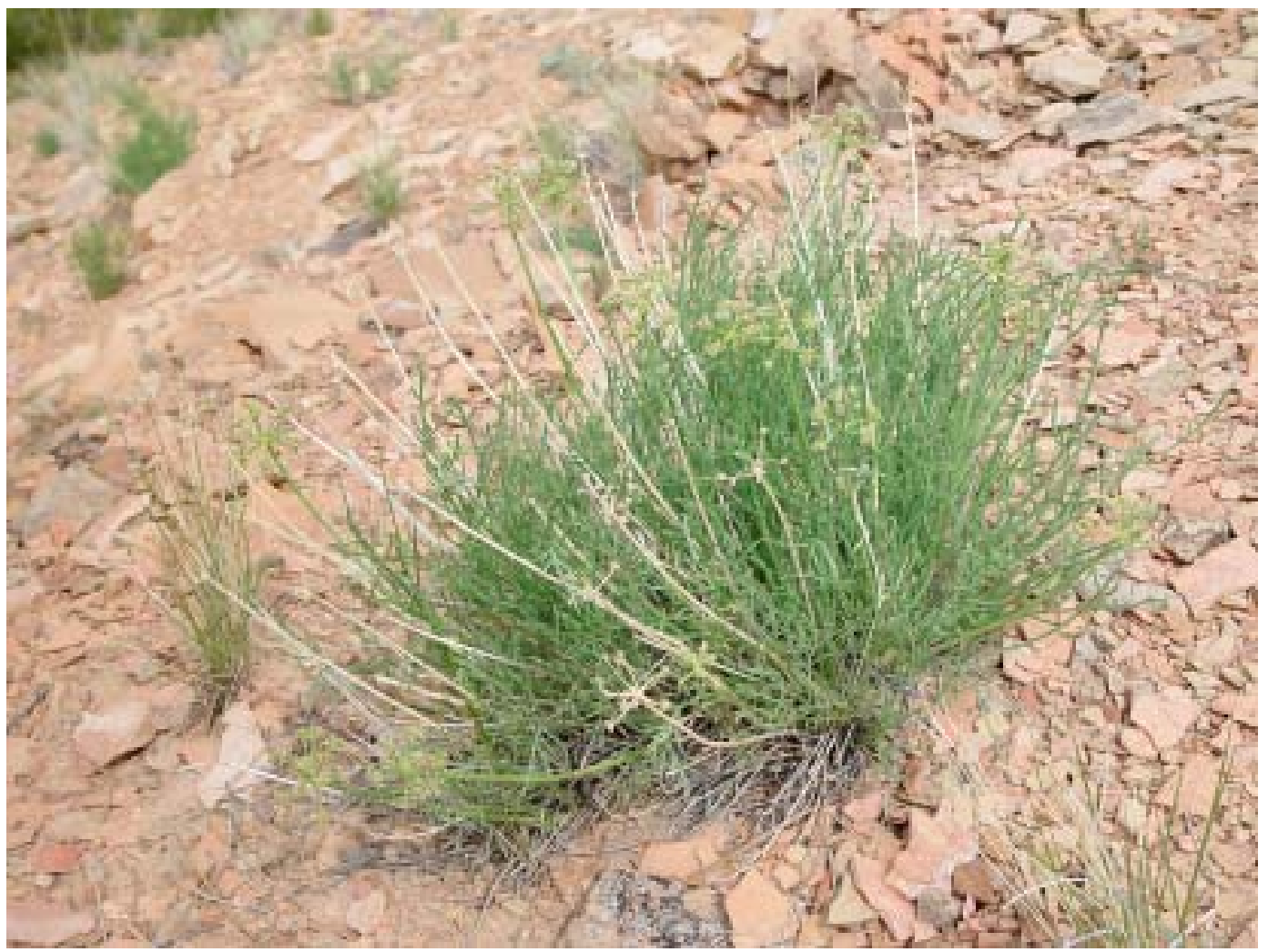

Figure 12. Lomatium nuttallii growth form. Tongue River, Rosebud County.

Old leaves remain at base of plant.

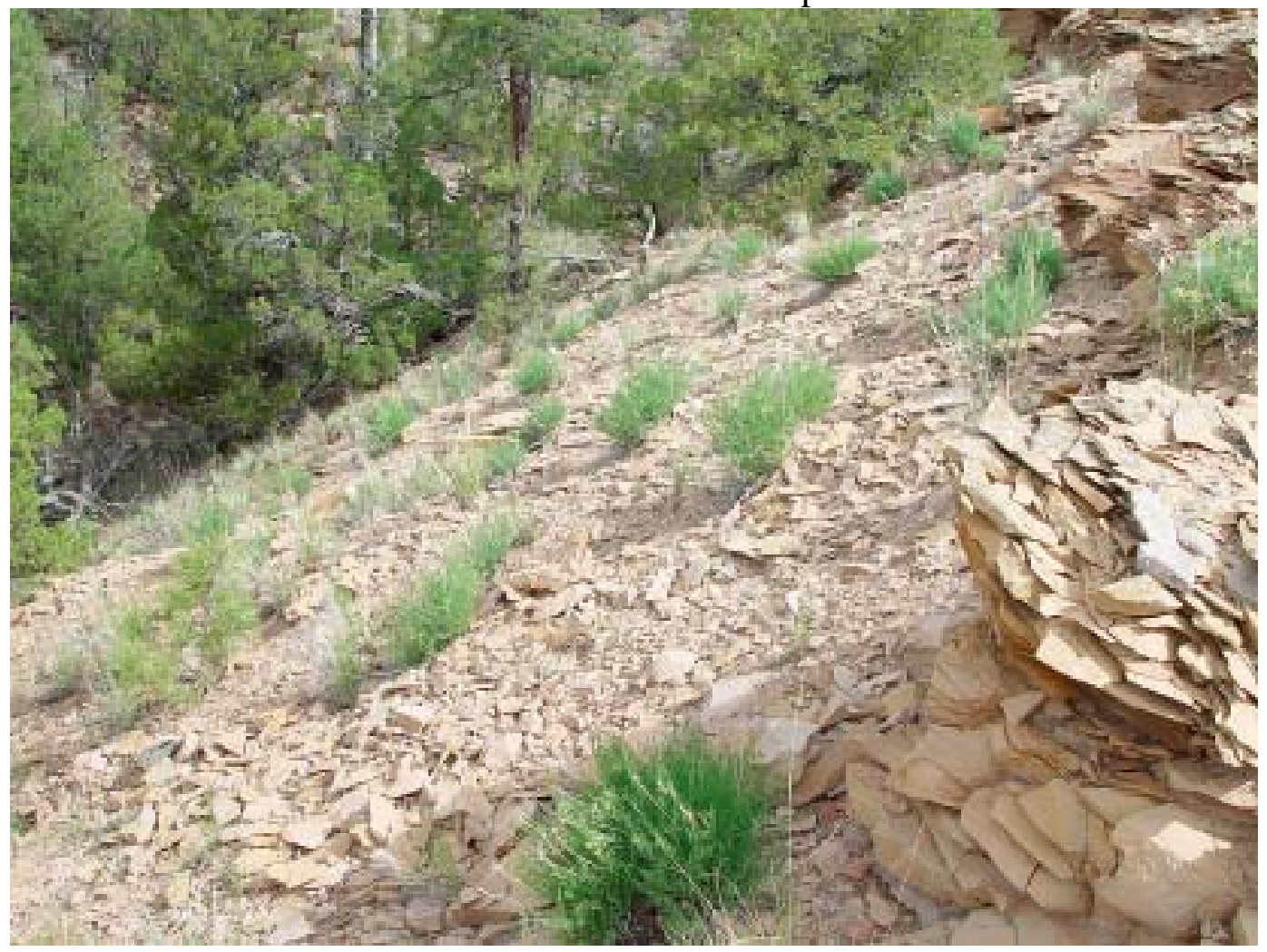

Figure 13. Lomatium nuttallii habitat above Tongue River, Rosebud County. 


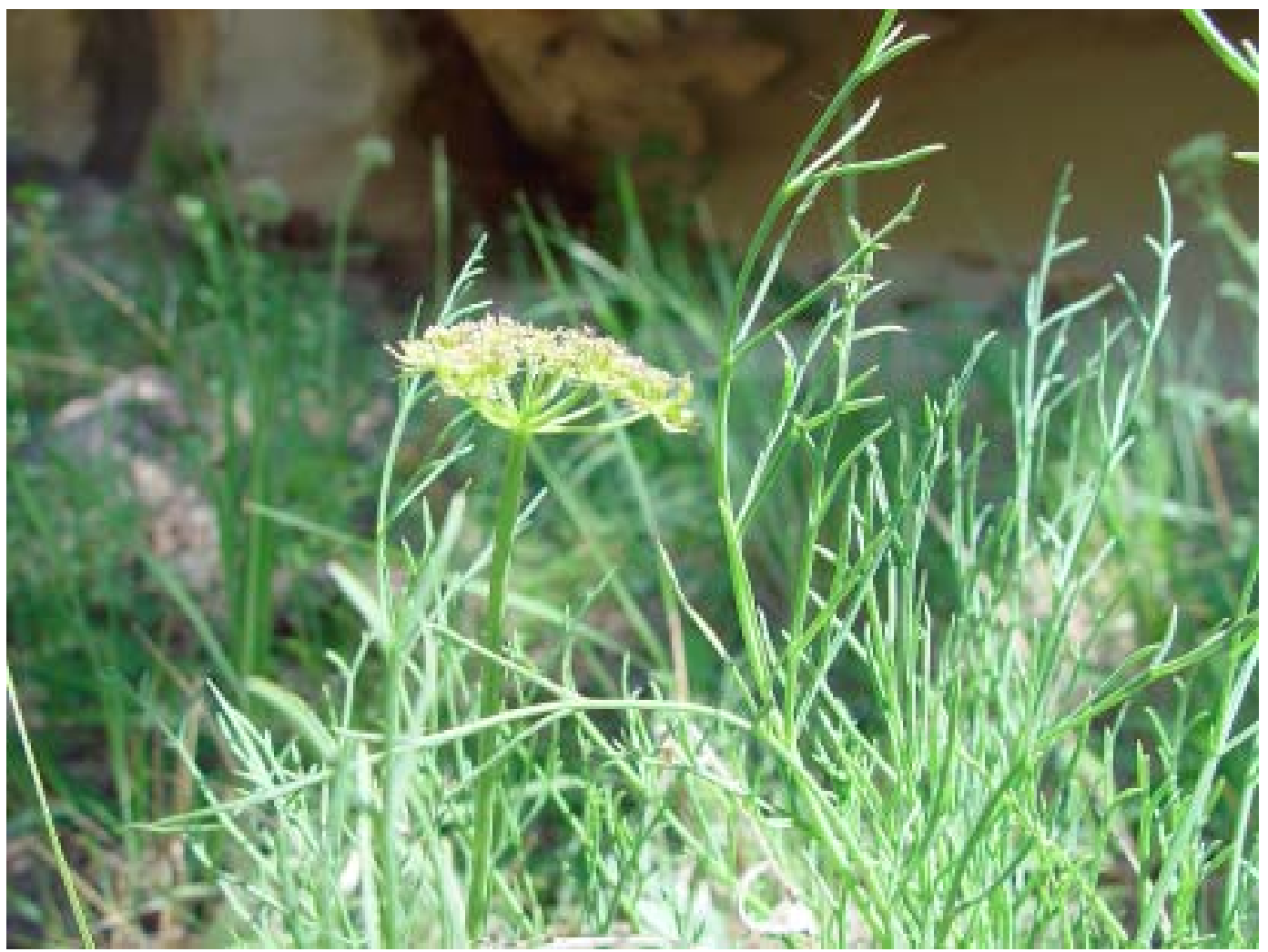

Figure 14. Lomatium nuttallii close-up showing leaf characteristics. Tongue River, Big Horn County.

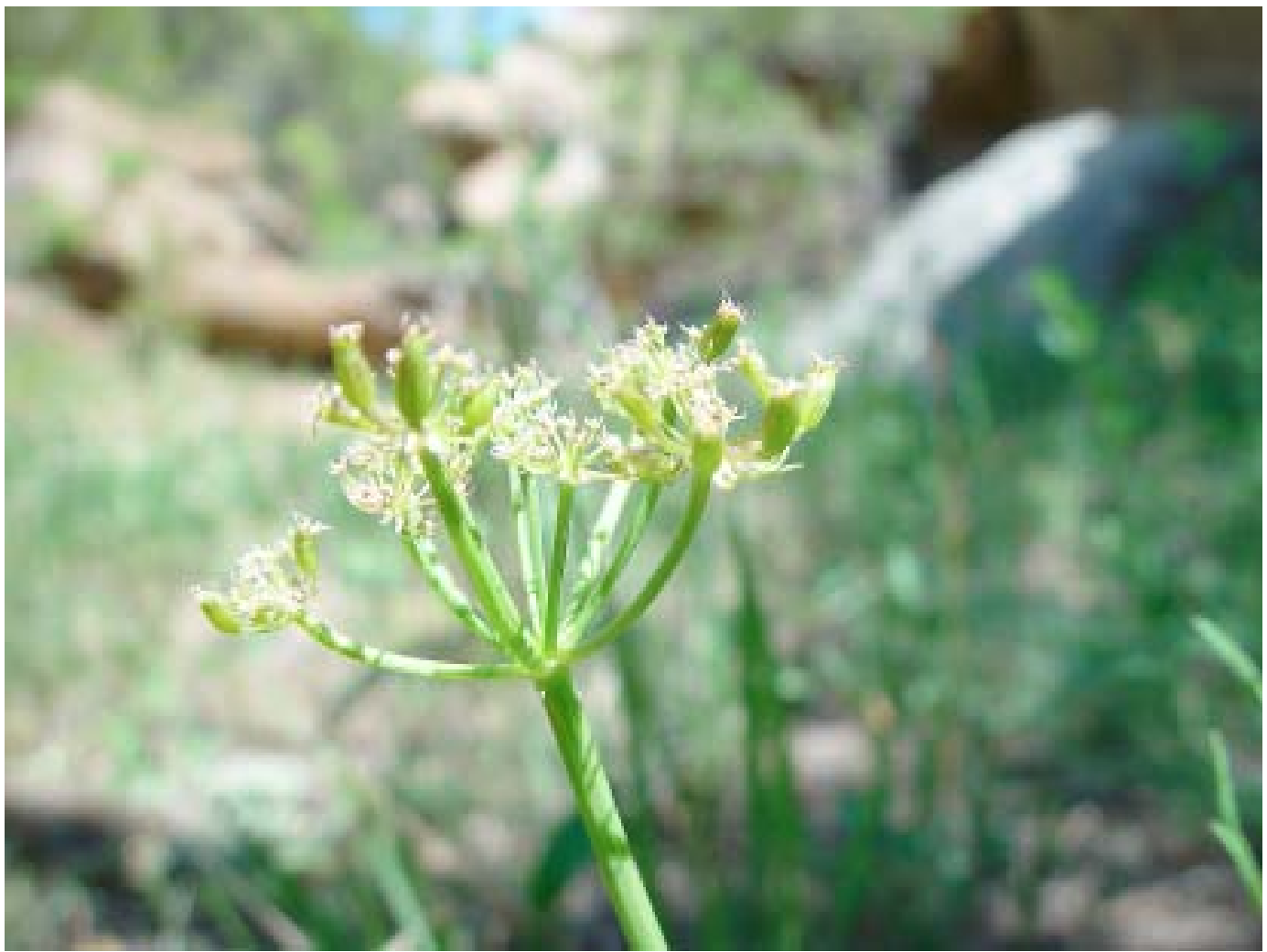

Figure 15. Lomatium nuttallii close-up showing fruit characteristics. Tongue River, Big Horn County. 


\section{Discussion and Conclusions}

\section{Distribution and Abundance}

This study produced significant new information on the distribution and habitat characteristics of Astragalus barrii (Barr's milkvetch), Physaria didymocarpa var. lanata (woolly twinpod) and Lomatium nuttallii (Nuttall's desert-parsley) in southeastern Big Horn and southwestern Rosebud counties and in the state as a whole, since the latter two species are known to occur only in this area of Montana. A key question is whether, based on this information, we can reliably predict where these species might occur, or extrapolate their frequency and abundance across the landscapes in which they occur.

Based on the habitat information we gathered, none of these species occupy landforms or vegetation types that are especially rare in this landscape. On the contrary, their habitats, while fairly distinctive, are quite common in the region; shale, clay siltstone, sandstone and red clinker characterize much of the study area. However, these species were often not present (or not found) in areas of apparently suitable habitat where we surveyed. This is underscored by the fact that we found them on only nine of our 25 survey routes. Since most survey routes covered more than one potential habitat site, our actual success rate for finding these plants in apparently suitable habitat was even lower. This affirms that they are still uncommon to rare, and do not occur predictably and regularly in apparently suitable habitat.

Our surveys primarily focused on large blocks of public land; other populations may well exist on smaller blocks of public land that were not surveyed. For example, the population of Nuttall's desert-parsley found in Rosebud County was on an isolated ${ }^{\circ}$ section of BLM land. Even in those larger BLM management units where we focused our work, surveys were by no means exhaustive, since the areas are large (measured in square miles) and the country is not easy to traverse. See maps in Appendix 2 for exact search routes.) It is therefore quite possible that additional populations exist even in the blocks where we conducted surveys.

Finally, there is extensive private land in this region, and with very limited exceptions our surveys did not include private land. The public land that we surveyed was widely scattered, and travel between locations afforded the opportunity to visually assess miles of land that could be seen from the roads. Based on general habitat profiles and on-theground experience, casual observation identified significant potential habitat elsewhere throughout the area, most on unroaded private land with restricted access. It is reasonable to assume that some of these potential habitat sites support additional populations of the target species.

\section{Conservation and Management}

Few studies have considered factors that may affect the long-term viability of these species. Heidel \& Marriott (1996) indicate that A. barrii is found on secondary range, and is characterized by a low, tufted growth form and early-season flowering. The species is, therefore, minimally affected by grazing management, unless livestock developments are placed near populations or unless grazing causes major shifts in plant communities that result in increased competition. Another indirect impact of grazing could be the introduction or increase of invasive species; both the exotic yellow sweetclover (Melilotus officinalis) and the native Venusís looking glass (Triodanis perfoliata) have been observed to dominate near some heavily grazed areas. It has also been suggested that herbicide or early-season pesticide spraying could potentially affect Barr's milkvetch (Heidel \& Marriott 1996), or any other Species of Concern located close to weed treatment areas.

Little information about regarding the ecology of woolly twinpod and Nuttall's desert-parsley exists. However, populations of both species were observed close to areas that were being grazed at the time of this study. Given the generally sparse vegetation associated with these species, their 
habitat could be characterized as suboptimal range suggesting little or no threat from grazing. Woolly twinpod was also found on road cuts, which are often particularly vulnerable to erosion and weed invasions.

Both woolly twinpod and Nuttall's desert-parsley sometimes occur on unstable habitats that may not be easily conserved on a site-specific basis, and may be better suited to a larger strategy based on compatible management. For example, one population of Nuttall's desert-parsley in Big Horn County was found in a stream channel, which would likely be subject to the scouring effects of runoff associated with a heavy rain. Further information on the ecology and distribution of these species will be needed to confidently propose longterm management strategies.

Given that the landscape inhabited by these plants is relatively undeveloped and ecologically intact at present, the greatest potential negative impact to all three species would be extensive developments resulting in widespread conversion and/or fragmentation of native habitat and vegetation. In the past, surface coal mining has resulted in intensive though fairly localized impacts. Interestingly, woolly twinpod was first discovered in Montana in 1993 close to the Spring Creek Coal operation. This population was re-surveyed in 2001 and still supports the largest population of woolly twinpod documented in Montana, as well as a very large population of Barr's milkvetch.

Barr's milkvetch and, to some extent, woolly twinpod, tend to occupy high knobs and outcrops that are perhaps less likely to be selected as sites for mineral development. However they may still be vulnerable to secondary threats that result from extensive disruption of native vegetation, such as the introduction and spread of aggressive invasive weeds that reduce habitat quality and compete with native plant species.

Related to weeds, we incidentally observed the exotic weed, Halogeton glomeratus (saltlover), at several locations during our field surveys in 2002. This weed is known to be poisonous to livestock, with sheep being especially susceptible.
It is well adapted to high salt levels, and leachates from its herbage will concentrate salts on the soil surface, further inhibiting competing plant growth (Young 2002). Increasing salinity of the soil could encourage spread of this species at the expense of native forage plants.

Nuttall's desert-parsley grows on mid- to lowerslopes, especially along drainages-a habitat that could be more vulnerable to extractive development. All three known populations were found along, or closely bordering, drainages, implying a possible association with the availability of soil moisture that can be stored by the long taproots. Thus changes to the current hydrologic conditions may have the potential to impact these populations. However, there is still too little known about its distribution and ecology to make strong inferences about its conservation and management.

In general, larger populations may stand a better chance of surviving some disturbance, with the many smaller populations perhaps being less resilient. It has also been suggested (Heidel and Marriott 1996) that larger populations of Barr's milkvetch appear to be buffered against drought conditions.

\section{Species Status Recommendations}

Woolly twinpod is now known from five locations in the state, and it is likely that more populations exist in Montana. One Montana population numbers over one thousand plants, however the other two are much smaller (ranging from 16-100 individuals) and occupy small, localized habitats. This species has a rank of G5T2 S1, indicating its highly restricted distribution in Montana. The largest known population on BLM land is along Tidwell Creek and appears to be stable and productive. The Zook Creek population lies within a BLM Wilderness Study Area. Based on its global and state rank, this species warrants consideration for addition to the BLMís Sensitive or Watch list.

Nuttall's desert-parsley has been recorded at three separate locations in the state, and is ranked G3 $\mathrm{S} 1$, indicating its highly restricted distribution in 
Montana. This species is presently on the BLM Watch list and is worthy of consideration for Sensitive status. The largest population is on a small BLM $^{\circ}$ section surrounded by private land, and the other populations are either small or on private land.

Barr's milkvetch is far more widespread, with 35 occurrences currently documented in Montana, and a rank of G3 S2S3. Many occurrences, including several large populations, lie on BLM land and in the Custer National Forest (where it is designated USFS Sensitive and threats are probably low). Perhaps the largest population in the study area is adjacent to the Spring Creek Mine on private land. This population could be impacted by future expansion of mining activity. Another sizeable population lies on BLM land between Squirrel Creek and the South Fork Spring Creek. Two additional locations outside this study area, northeast of Birney, support large populations - the Kings Creek Well site on the Custer National Forest and the Gate Creek site, part of which lies on BLM land.

Survey work over the past few years continues to document new populations of Barr's milkvetch. The number and widely scattered distribution pattern of populations makes this species somewhat less vulnerable to extirpation. It may at some point be considered secure enough for downgrading from special management status if more healthy populations continued to be discovered, and if most populations (including the larger ones) are verified to be stable, under compatible management and not at risk from current or impending land uses. However, at present, the current BLM designation of Watch seems appropriate.

\section{Recommendations for Future Work}

As noted previously, the fact that habitat for these three species is widespread in the study area indicates a high likelihood that additional populations remain undiscovered (Schassberger 1990; Taylor 2001; Barton pers. obs.). BLM staff who conduct range assessments or other fieldwork within the study area are encouraged to become familiar with field recognition of $A$. barrii, $P$. didymocarpa var. lanata and $L$. nuttallii.

A. barrii should be surveyed from early to midMay when it is typically in full bloom. Dried remnant flowers often lose their color, making the species more difficult to confidently identify. Both $P$. didymocarpa var. lanata and L. nuttallii can be identified later in the year using vegetative and fruiting characteristics.

With sufficient data (spatial coverages for soils, aspect, slope, vegetation cover, etc.), it would be possible to model and map potential habitat for these species across the landscape. Such an analysis could help better assess the extent of potential habitat and make tentative extrapolations about the speciesí possible abundance. It would also help focus any future surveys on areas with the best potential habitat. Expanding surveys to include private land, with landowner cooperation, would also help to better document speciesí distribution and abundance. Discovering and documenting additional populations can even, in some cases, provide evidence that a species is sufficiently common and/or compatible with current land uses to warrant downgrading or removal of special designation status. 


\section{References}

Bureau of Land Management (BLM). 1996. Special Status Species Plant Policy. Montana State Office, Department of the Interior. 49 pages.

Carlson, J. C. and S. V. Cooper. 2003. Plant and Animal Resources and Ecological Condition of the Forks Ranch Unit of the Padlock Ranch, Big Horn County, Montana and Sheridan County, Wyoming. Unpublished report to The Nature Conservancy Montana Field Office. Montana Natural Heritage Program, Helena. 18 pp. plus appendices.

Cronquist, A. et al. Intermountain Flora. Vascular Plants of the Intermountain West, U.S.A. Volume Three Part A. Hafner Publishing Co., New York and London. 1997. 446 pages.

Dorn, R. D. 1992. Vascular Plants of Wyoming, Second Edition. Mountain West Publishing, Cheyenne, Wyoming. 340 pages.

Dorn, R. D. 2001. Vascular Plants of Wyoming, Third Edition. Mountain West Publishing, Cheyenne, Wyoming. 412 pages.

Fertig, W. 2000. State Species Abstract: Physaria didymocarpa var. lanata. Wyoming Natural Diversity Database, Laramie, Wyoming. 2 pages.

Heidel, B. L. and H. Marriott. 1996. Sensitive Plant Species Survey of the Ashland District, Custer National Forest, Powder River and Rosebud Counties, Montana. Unpublished report to the Custer National Forest. Montana Natural Heritage Program, Helena, Montana. 94 pages plus appendices.

Heidel, B. L. and J. Vanderhorst. 1999. Sensitive Plant Species Surveys: Butte District, Beaverhead and Madison Counties, Montana. Report to the Bureau of Land Management, Billings. Montana Natural Heritage Program, Helena, Montana. 85 pages plus appendices.

Schassberger, L. A. 1990. Report on the Conservation Status of Astragalus barrii, a Candidate Threatened Species. Unpublished report to the U.S. Fish \& Wildlife Service, Denver. Montana Natural Heritage Program, Helena, Montana. 85 pages.

Soil Survey of Rosebud County Area and Part of Big Horn County, Montana: Part I and Part II. 1996. United States Department of Agriculture, Natural Resources Conservation Service. In cooperation with Montana Agricultural Experiment Station.

Taylor, A. and R. Caners. 2001. Baseline Survey for Astragalus barrii Barneby (Barr's Milkvetch) and Physaria didymocarpa var. lanata A. Nels. (Woolly Twinpod) in Eastern Big Horn and Southwestern Rosebud Counties, Montana. Montana Natural Heritage Program, Helena, Montana. 27 pages.

United States Department of Agriculture (USDA), Natural Resources Conservation Service (NRCS). 2000. Montana Key for Ecological Sites. Unpublished Draft (10/2000) on file at the Montana Natural Heritage Program. 7 pages.

Young, J.A. 2002. Halogeton Grazing Management: Historical Perspective. Journal of Range Management. 55(3): 309-311. 


\section{Appendix 1. Global / State Rank Definitions}




\section{Appendix 1. Global / State Rank Definitions}

\section{HERITAGE PROGRAM RANKS}

The international network of Natural Heritage Programs employs a standardized ranking system to denote global (range-wide) and state status (NatureServere 2003). Species are assigned numeric ranks ranging from 1 (critically imperiled) to 5 (demonstrably secure), reflecting the relative degree to which they are "at-risk". Rank definitions are given below. A number of factors are considered in assigning ranks ó the number, size and distribution of known "occurrences" or populations, population trends (if known), habitat sensitivity, and threat. Factors in a speciesílife history that make it especially vulnerable are also considered (e.g., dependence on a specific pollinator).

\section{RANK DEFINITIONS}

G1 S1 Critically imperiled because of extreme rarity and/or other factors making it highly vulnerable to extinction.

G2 S2 Imperiled because of rarity and/or other factors making it vulnerable to extinction.

G3 S3 Vulnerable because of rarity or restricted range and/or other factors, even though it may be abundant at some of its locations.

G4 S4 Apparently secure, though it may be quite rare in parts of its range, especially at the periphery.

G5 S5 Demonstrably secure, though it may be quite rare in parts of its range, especially at the periphery.

GU SU Possibly imperiled, but status uncertain; more information needed.

GA SA Native in nearby states, but in Montana believed to be accidentally introduced, deliberately planted, or escaped from plantings.

GH SH Historical, known only from records over 50 year ago; may be rediscovered.

GXSX Believed to be extinct; historical records only.

\section{COMBINATION RANKS}

$\mathrm{G} \# \mathrm{G} \#$ or $\mathrm{S} \# \mathrm{~S} \#$ Indicates a range of uncertainty about the rarity of the species.

\section{SUBRANKS}

$\mathrm{T} \#$

Rank of a subspecies or variety; appended to the speciesí global rank of the full species, e.g. G4T3.

\section{QUALIFIERS}

Q Taxonomic questions or problems exist, more information needed; appended to the global rank, e.g. G3Q.

? Denotes uncertainty or for numeric ranks, inexactness. 


\section{Appendix 2. Maps of the Search Routes}




\section{Appendix 2. Maps of the Search Routes}

Solid red lines indicate search routes. Astragalus barrii locations are marked by blue dots, Physaria didymocarpa var. lanata locations are marked by black dots and Lomatium nuttallii locations are marked by yellow dots. The large blue and yellow circles in Appendix 2.1 represent occurrences with locational uncertainty based on information from collectors.

The 1:24,000 USGS Quad names associated with each map are as follows:

\section{Quad Name}

Appendix 2.1

Decker

Half Moon Hill

Pearl School

Toungue River Dam

Appendix 2.2

Holmes Ranch

Lacey Gulch

Pine Butte School

Spring Gulch

Appendix 2.3

Forks Ranch

Hamilton Draw

Quietus

Stroud Creek

Appendix 2.4

Birney

Birney SW

Clubfoot Creek

Spring Gulch

Taintor Desert

Toungue River Dam 


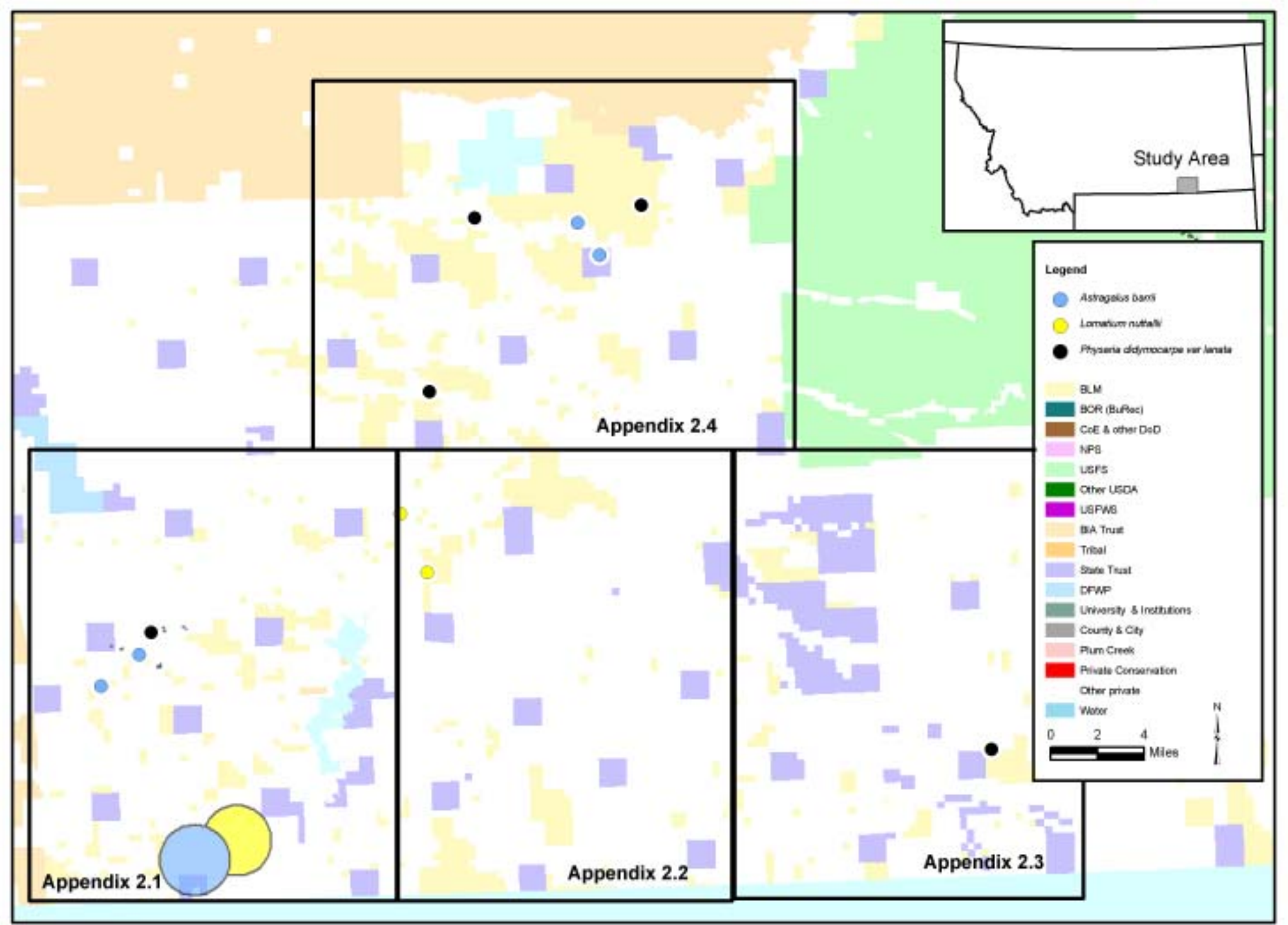

Appendix 2. Overview of the four maps that follow known occurrences of Astragalus barrii, Physaria didymocarpa var. lanata and Lomatium nuttallii. 


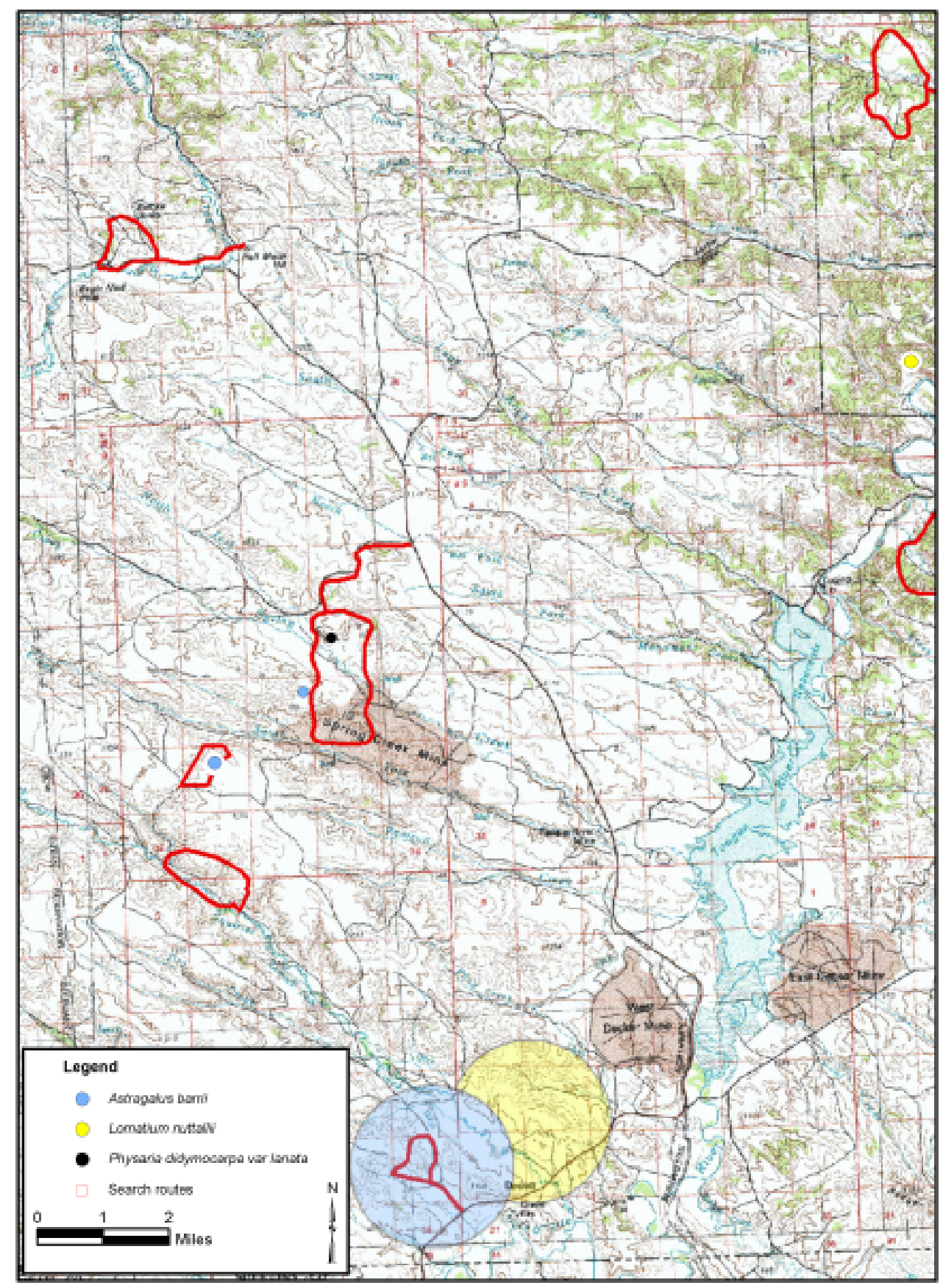

Appendix 2.1 Solid red lines indicate search routes. The large blue and yellow circles represent occurrences that have higher uncertainty as to exact location of the population. 


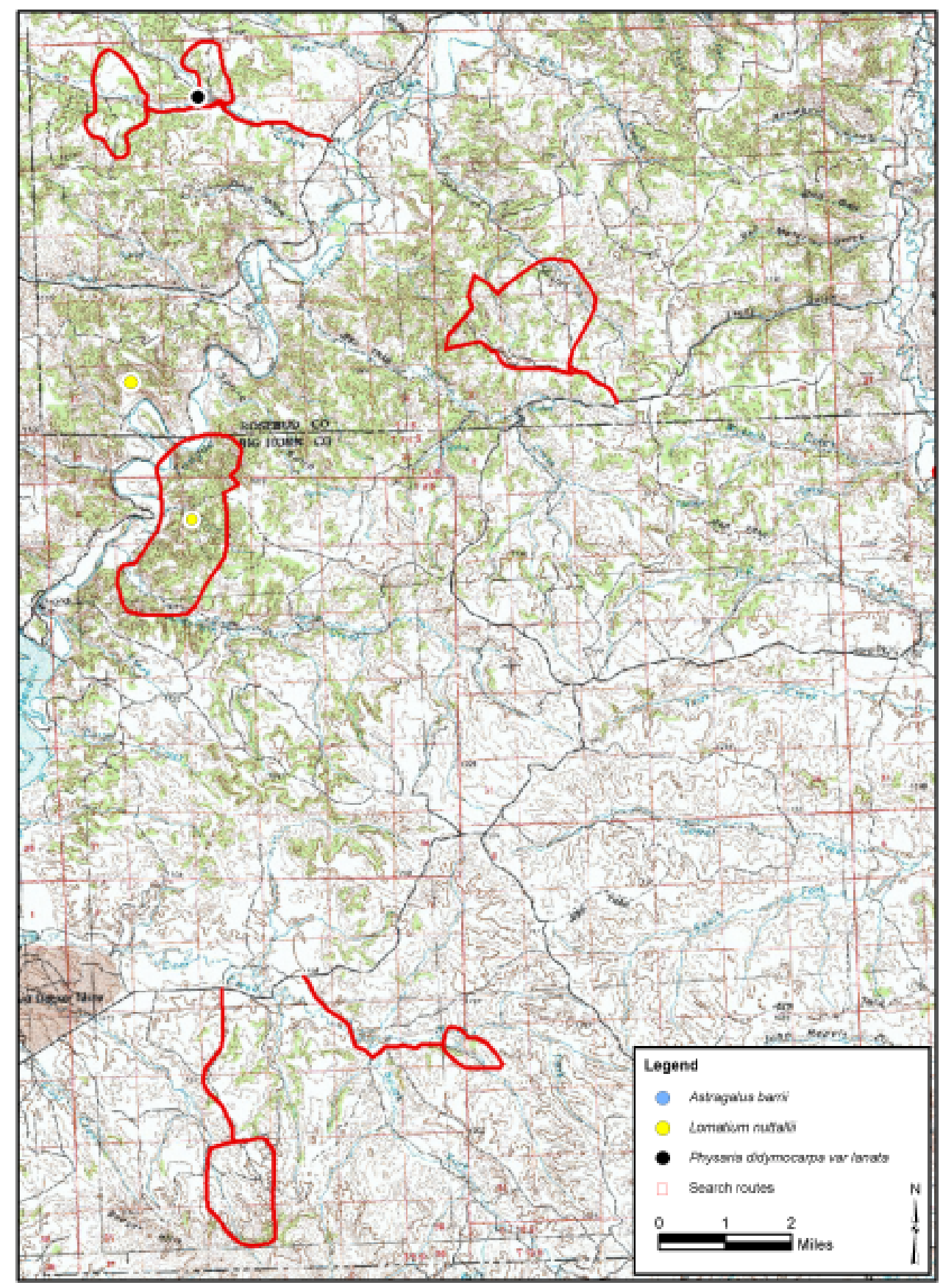

Appendix 2.2 Solid red lines indicate search routes. 


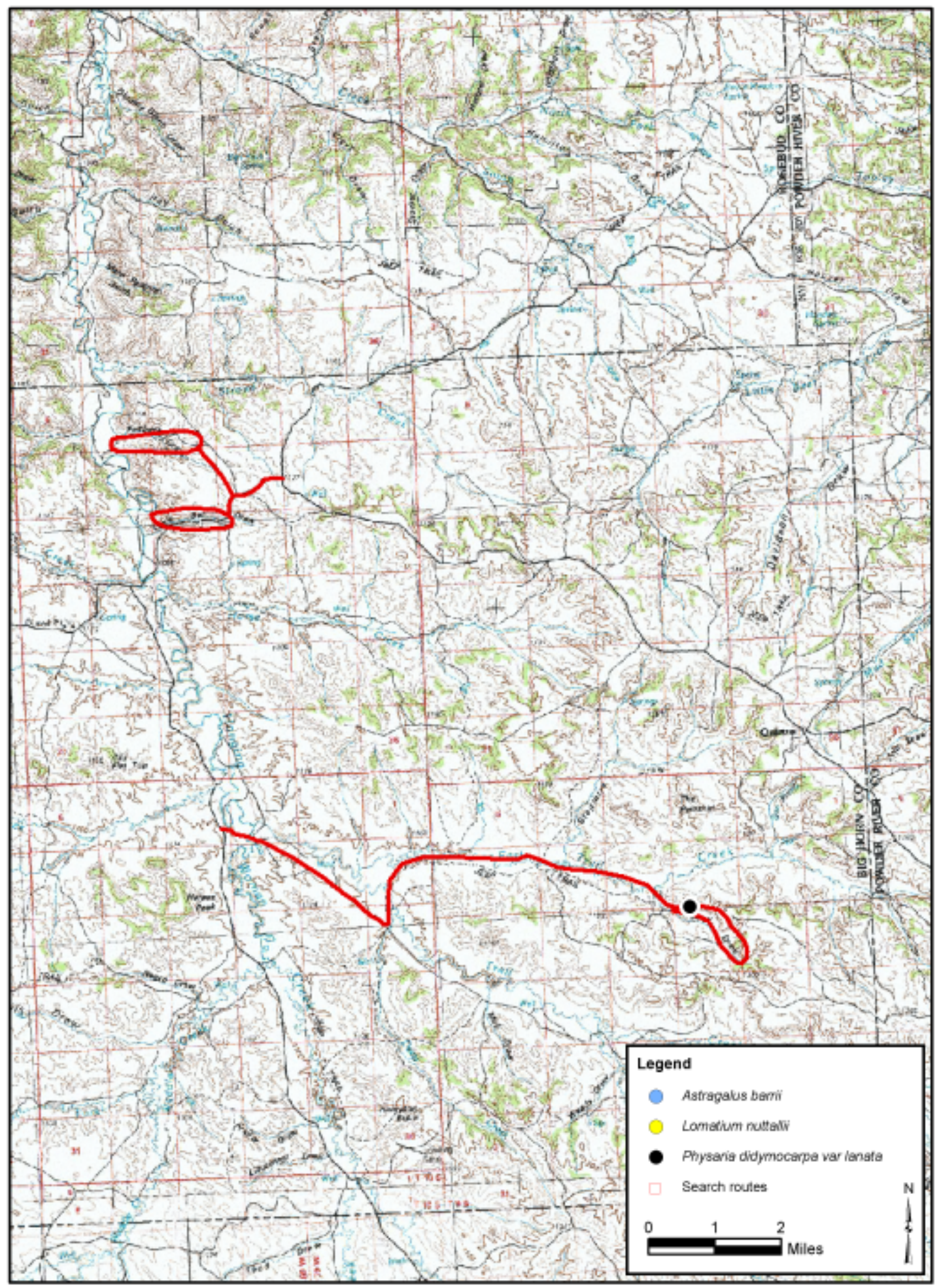

Appendix 2.3 Solid red lines indicate search routes. 


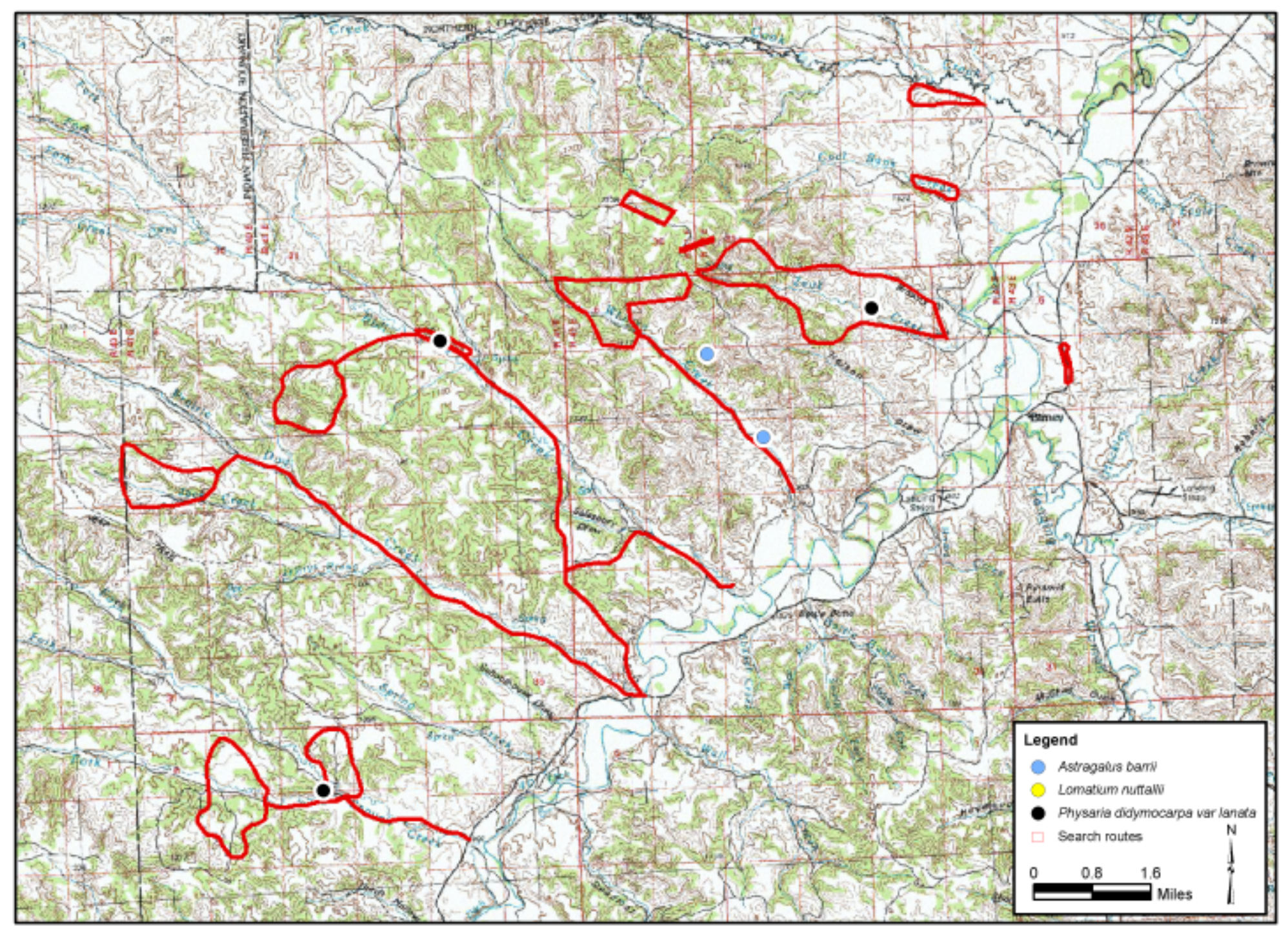

Appendix 2.4 Solid red lines indicate search routes. 